\title{
When the "Haves" Hold Court: Speculations on the Organizational Internalization of Law
}

\begin{abstract}
Marc Galanter's 1974 essay, "Why the 'Haves' Come Out Ahead," portrayed large bureaucratic organizations as the archetypal repeat players in the legal system; Galanter's account, however, devoted relatively little attention to the distinctive legal capacities of organizations as organizations. This article extends Galanter's analysis by considering the ability of large bureaucratic organizations to "internalize" legal rules, structures, personnel, and activities. Specifically, we posit that the relationship between law and organizations has undergone four interrelated shifts in recent years: (1) the legalization of organizational governance, (2) the expansion of private dispute resolution, (3) the rise of in-house counsel, and (4) the reemergence of private policing. These processes interact with one another to transform the large bureaucratic organization from being merely a repeat player in the public legal system to being a full-fledged private legal system in its own right. Although "have not" groups may gain some short-run advantages from the introduction of citizenship norms into the workplace, the organizational annexation of law subtly skews the balance between democratic and bureaucratic tendencies in society as a whole, potentially adding to the power and control of dominant elites.
\end{abstract}

A

the core of Marc Galanter's pathbreaking 1974 article, "Why the 'Haves' Come Out Ahead: Speculations on the Limits of Legal Change," lies the distinction between those litigants who are "one shotters" and those who are "repeat players." Galanter (1974:98-99) argues that repeat players enjoy numerous advantages in the legal system, including (1) advance intelligence and the ability to preplan transactions; (2) ongoing access to specialists, reduced start-up costs, and economies of scale; (3) informal facilitative relationships with institutional incumbents; (4) longrun strategic interests and the ability to "play for rules"; and (5)

Authorship of this paper was fully collaborative. The authors would like to express their appreciation to the Institute for Legal Studies at the University of Wisconsin for organizing the conference that inspired this essay. Thanks also go to Richard Lempert, Elizabeth Joh, Deborah Carr, and four anonymous Law $\mathcal{E}$ Society Review referees for their insightful commentary on earlier drafts and to Iona Mara-Drita and Dan Steward for their able research assistance. Address correspondence to Lauren B. Edelman, Center for the Study of Law and Society, School of Law, University of California-Berkeley, Berkeley, CA 94720-2150 (e-mail: <ledelman@uclink4.berkeley.edu>), or to Mark C. Suchman, Department of Sociology, University of Wisconsin-Madison, 1180 Observatory Dr., Madison, WI 53706 (e-mail: <suchman@ssc.wisc.edu>). 
experience in discerning which rule changes are likely to "penetrate" into the law in action. Overall, Galanter suggests that these and other repeat player advantages significantly impede the efforts of one shotters to achieve significant social reforms through recourse to the legal system.

Although Galanter draws the dichotomy between one shotters and repeat players primarily in abstract structural terms, his description leaves little doubt that in modern American society, the archetypal repeat player is the large bureaucratic organization (e.g., 1974:97, 113). ${ }^{1}$ Consistent with Galanter's definition of a repeat player, the typical large bureaucratic organization generally "has and anticipates repeated litigation, ... . and has the resources to pursue its long-run interests" (1974:98). Organizations take advantage of this repetition by employing all the classic long-term strategies described above. They enlist specialist attorneys to structure future transactions, they routinize their business and legal dealings to exploit economies of scale, and they lobby and litigate to secure favorable statutes and precedents. Moreover, with the rules primarily on their side, organizations also benefit from passive and overburdened judicial institutions, which make it difficult for others to challenge the status quo.

As perceptive as Galanter's 1974 account may have been, however, it omitted several aspects of organizations' law-oriented behavior that, although barely noticeable at the time, have since become significant features of the legal landscape. Galanter's portrait generally depicted organizations merely as ordinary (albeit privileged) parties in the traditional plaintiff-defendantjudge triad-parties who, to a large extent, remained dependent on state-made rules, public dispute resolution, independent lawyers, and governmental law enforcers. Admittedly, Galanter took care to note that organizations also participated in alternative disputing arenas, such as court-appended forums, direct negotiations "in the shadow of the law" (Mnookin \& Korhauser 1979), and private arbitration proceedings. Even here, however, an external legal decision maker presumably stood above and separate from the disputing parties, either immediately or as a future threat.

In contrast, the following pages offer a somewhat more complex image of how organizational repeat players encounter the law. Specifically, we hypothesize that since 1974, large bureaucratic organizations have increasingly "internalized" important

1 Although some of the arguments discussed below apply with equal force to all organizations regardless of size and structure, our analysis focuses primarily on the large bureaucratic organizations that form the core of the modern economy and polity. Only this subset of the organizational world enjoys the material and cultural capacity to implement fully the strategies described here. Smaller organizations, although still often among society's "haves," generally face a more restricted set of legal options. 
elements of the legal system. ${ }^{2}$ This internalization, we argue, has taken at least four forms: (1) legal rule making has been internalized through the "legalization" of individual firms and of larger organizational fields, (2) legal dispute processing has been internalized through the increasing use of alternative dispute resolution in both intra- and interorganizational conflicts, (3) legal expertise has been internalized through the growing prominence and changing role of in-house counsel, and (4) legal enforcement has been internalized through the reemergence of private organizational security staffs. Together, these shifts carry the potential to transform the large bureaucratic organization from being merely a structurally privileged actor in the public legal order to being a private legal order in its own right. In a very real sense, we suggest, today's organizations hold court, incorporating but also subsuming many of the public legal system's central functions. As private legislatures, courthouses, law offices, and police departments, organizations construct within and around themselves a semiautonomous legal regime that simultaneously mimics and absorbs even the most "official" institutions of governmental law.

To date, sociolegal scholarship has rarely examined this internalization of law as a coherent phenomenon, and the available evidence, although suggestive, remains sketchy and disorganized. For this reason, we treat the four components of the internalization process as hypotheses rather than as proven facts. In the spirit of Galanter's "speculations on the limits of legal change," the following pages offer speculations on the extensiveness of organizational change. Like Galanter's original essay, this article seeks to highlight "general features of a legal system like the American by drawing on (and rearranging) commonplaces and less than systematic gleanings from the literature" (Galanter 1974:95). For each internalization hypothesis, we muster a substantial body of evidence and argumentation; however, we leave conclusive testing of these hypotheses to the future efforts of researchers throughout the law and society community. Our primary objectives here are simply to suggest that several apparently distinct bodies of research may actually fit together into a larger picture, and to consider the implications of that picture for the relationship between society's "haves" and "have nots." Because the composite image has only recently begun to emerge, our arguments are necessarily tentative and conjectural; if true, though, they imply significant changes in the contours of the modern legal order.

To explore these changes, this article examines the nature of organizations as private legal orders. We begin the exploration

2 The organizational internalization of law may represent a special case of Perrow's (1991:726) more sweeping assertion that "large organizations have absorbed society. They have . . made organizations, once a part of society, into a surrogate of society." 
by presenting the four internalization hypotheses in detail and by surveying the existing evidence on each. We then discuss the ways in which the hypothesized trends, if they are indeed occurring, may carry the potential to transform organizations into private legal orders. Finally, we consider the implications of this transformation for the larger social system: ${ }^{3}$ If the "haves" come out ahead as repeat players, how do they come out when they hold court? Although "have not" groups may gain some shortrun advantages from the introduction of legal norms into the workplace, we contend that the organizational annexation of law subtly skews the balance between democratic and bureaucratic tendencies in society as a whole, potentially adding to the power and control of dominant elites.

\section{The Internalization of Law}

The years since 1974 have brought substantial shifts in the characteristics of large bureaucratic organizations, in the characteristics of the formal legal system, in the relationship between organizations and law, and in our knowledge of all three. This section discusses several of these developments. Specifically, we propose four interrelated hypotheses about the organizational internalization of law, and we draw together various secondary data supporting these hypotheses. Much, but not all, of this evidence comes from the area of employment law, because the employment relation has attracted considerable attention from organizational and sociolegal scholars in recent years. Nonetheless, we believe that our internalization hypotheses pertain to other legal topics as well, and we present data from nonemployment contexts whenever possible. The existing body of theory and research strongly suggests that internalization operates in similar ways across most, if not all, areas of law, and future research would do well to consider the workings of this phenomenon wherever it may occur.

To understand the organizational internalization of law, one must recognize that each hypothesized transformation has occurred at two levels simultaneously: within organizations and throughout organizational fields. ${ }^{4}$ This simultaneity is by no

3 Our analysis focuses primarily on the likely effects of internalization, rather than on its causes. Although both topics merit scholarly attention, we follow Galanter in choosing to emphasize the impact of particular institutional arrangements on the societal balance of power while remaining largely agnostic about the processes that brought those arrangements into existence in the first place. Others (including ourselves, elsewhere) have devoted substantial attention to delineating the social forces that drive organizations to internalize central elements of public law; here, however, our attention turns instead to sketching the ways in which such internalization may, reciprocally, reshape the workings of the sociolegal order itself.

4 Organization theorists use the concept of an "organizational field" to describe a system of social relations that makes up a relatively discrete and immediate chunk of the organizational environment, larger than an individual firm but smaller than an entire 
means coincidental. Recent work in "neoinstitutional" organizational sociology (see, e.g., Powell \& DiMaggio 1991; Scott 1995) suggests that new models and practices spread most rapidly when they become "institutionalized"-that is, "infused with value beyond the technical requirements of the task at hand" (Selznick 1948) - and such institutionalization generally proceeds through interactions between individual organizations and their fieldlevel environments. These interactions have both "top-down" and "bottom-up" components. Some new models and practices emerge from field-level discourses and diffuse downward, ${ }^{5}$ gaining legitimacy as individual organizations embrace them, implement them, and translate them into the lived experiences of organizational participants (DiMaggio \& Powell 1983; Scott \& Meyer 1983); other models and practices emerge from the innovations of individual organizations and migrate upward, gaining legitimacy as field-level discourses theorize them, systematize them and integrate them with the ongoing routines of the interorganizational environment (Suchman 1995a; Edelman et al. 1999). Thus, while changes in environmental conditions reconstruct individual organizations, changes in organizational behavior reciprocally reconstruct fields. Either way, the resulting institutional arrangements reflect both field-level and organizationlevel dynamics, and it would be a mistake to depict institutional change as solely the product of either isolated organizational decisions or undifferentiated collective rationales.

The four hypotheses that we discuss in this section involve such top-down and bottom-up institutionalization processes. Specifically, recent shifts in the structure of individual organizations and of organizational fields appear to be fostering a legalization of organizational governance, an expansion of alternative dispute resolution, a buildup of corporate in-house counsel staffs, and a proliferation of corporate private security forces. We suggest that each of these internalization dynamics represents an im-

society. The field around any particular focal organization includes "key suppliers, resource and product consumers, regulatory agencies, and other organizations that produce similar services or products" as well as the webs of information and influence that link these entities into a coherent enterprise (DiMaggio \& Powell 1983:148). By applying this definition to legal matters, one could, for example, discuss the role of law in the health care field, in the field of steelmaking, in investment banking, or in the performing arts.

5 The organizations literature supplies several explanations for this diffusion process. Some theorists emphasize the social construction of cognitive frames and behavioral scripts, suggesting that dominant models often become so ritualized and taken for granted that they serve as preconscious templates for action, literally "constituting" organizational behavior, independent of intentional agency by individual firms or their managers. Other theorists adopt a more eclectic stance, attributing the diffusion of institutionalized models not only to cognitive framing mechanisms, but also to an array of more conscious rational and normative motivations, coupled with internal and external structural pressures (cf. Suchman 1997). Thus, organizations might adopt institutionalized models to secure public resources, to obtain legitimacy, to pursue shared value commitments, or to ease communications with other actors in their field (Suchman \& Edelman 1996; Scott 1995; cf. Suchman 1995b). 
portant change in contemporary organizations' legal behaviors and appearances, and we hypothesize that although the extent of these changes varies, all are increasingly acquiring an institutionalized status.

\section{The Legalization Hypothesis}

In 1974, Galanter argued that repeat players benefit from their capacity to structure transactions in ways that give themselves positional advantages, should disputes subsequently arise. Further, according to Galanter, repeat players augment these positional advantages by playing for rules, that is, by actively pursuing favorable statutes, regulations, and judicial precedents. Today, as in 1974, repeat players continue to invest heavily in shaping public laws. Since the time of Galanter's initial analysis, however, researchers have increasingly suggested that large bureaucratic organizations also structure transactions through a more private process of internal "legalization": by creating and formalizing internal policies that approximate the core principles of legality-due process and substantive justice-large bureaucracies attempt to preempt and displace the interventions of public legal authorities (Selznick 1969; Nonet \& Selznick 1978; Edelman 1990). In mimicking the external legal order, organizations may manage, in effect, to construct their own legitimacy, winning the right not only to structure future transactions but also to establish the rules by which those transactions will be judged (Edelman 1992).

Organization theorists since Max Weber have of course noted that bureaucratic organization implies formal rule-making and hierarchical authority (Weber 1947), but the specific homology between organizational and legal rules attracted little attention until the publication of Philip Selznick's Law, Society, and Industrial Justice in 1969. Labeling this internalization of lawlike rulemaking "legalization," Selznick explored how administrative pressures and daily problem-solving challenges lead organizations to develop new workplace practices that draw on the public legal order for models of fairness and objectivity. Over time, these introjections of legality become institutionalized both within organizations as formal rules and procedures, and outside organizations as court rulings and statutes. Selznick argued that such legalization transforms organizations from being hierarchical systems that heed only official power to being normatively constrained polities that provide substantial "citizenship" rights for their members.

In recent years, neoinstitutional organizational sociologists have extended this line of analysis to locate the impetus for legalization not only in internal management challenges but also (and primarily) in the plethora of external strictures that organi- 
zations now encounter in the larger legal environment (Sitkin \& Bies 1994). New laws create new normative and cognitive preconditions for organizational activity, and organizations respond to these public legal ideals by constructing and displaying formal policies and structures that symbolize key tenets of the new regime (Edelman 1990; Sutton et al. 1994). Empirical work shows how legalization within organizations parallels changes in civil rights law (Baron et al. 1986; Edelman 1992; Schultz 1990; Dobbin et al. 1993; Sitkin \& Bies 1994; Sutton et al. 1994; Konrad \& Linnehan 1995), antipollution law (Hawkins 1984), disabilities law (Scheid \& Suchman 1998), and health and safety law (Bardach \& Kagan 1982; Rees 1988). In all these cases, organizational reactions have been both procedural and structural, taking the form of more (and more detailed) written rules, policies, and protections, and new law-related offices, positions, and programs.

Alongside such neoinstitutional analyses linking the legalization of organizational rule making to developments in the larger legal environment, a variety of competing noninstitutional accounts have generated substantial legalization literatures of their own. Traditional "rational" explanations for legalization have focused on the need for coordination and formalization both within and between firms, thus treating legalization as simply a special case of bureaucratization (Weber 1947; cf. Scott 1987; Sutton et al. 1994). Industrial relations theorists have argued that the threat of organized labor motivates employers to legalize as a way of convincing workers that unionization is unnecessary (Slichter 1919; Jacoby 1985). And critical theorists have pointed to legalization as a mechanism of bourgeois hegemony, a device for obscuring capitalist control by shifting the locus of power from direct coercion to impersonal, universalistic rules (Edwards 1979; Gordon et al. 1982). Despite their divergent explanatory frameworks, however, institutional and noninstitutional analyses largely agree on the contours of the underlying empirical phenomenon: all concur that organizational governance increasingly operates through legalized internal and external polities, with formal rules, rights, and procedures for appeal.

Empirically, the increase in legalization since the publication of Galanter's 1974 essay is especially apparent in the context of employee rights, an area in which the research literature offers several large-scale longitudinal studies. Edelman (1992) reports that in a sample of 346 organizations, only 30 had antidiscrimination guidelines in place in 1969, 118 instituted such rules in the 1970s (mostly between 1975 and 1980), and 75 more followed suit in the 1980s. Edelman's data also reveal a sharp jump in other forms of legalization during the 1970s, including the spread of special offices devoted to civil rights issues and special procedures for processing discrimination complaints. Similarly, in a study of 300 organizations, Sutton et al. (1994) find that the 
number of organizations granting the right to a formal disciplinary hearing increased steadily from 1955 to 1990 , with the steepest rise coming after 1975 .

In addition to these organization-level trends, scattered evidence suggests that organizational fields themselves may be becoming more legalized as well. The most obvious source of fieldlevel legalization is the proliferation of industry-specific statutes, regulations, and judicial doctrines (Galanter \& Rogers 1991; Blumrosen 1993; Nelson 1994: 349-50). Organizational fields, however, also become more legalized because of increasingly complex private governance regimes (e.g., contracts, associations, joint ventures, holding companies, mergers) among their constituent firms (see generally Nelson 1994:350-52). Equally significantly, changes in both public and private governance open niches for new (and old) professions, each with its own set of rationalized definitional categories and formalized ethical precepts (see, e.g., Edelman et al. 1992; Dezalay \& Garth 1996; Suchman \& Cahill 1996). Through the interaction of these mechanisms, formal rules increasingly become the accepted way of enforcing or reflecting institutional norms at the field level as well as at the organizational level. This pattern holds true not only for civil rights, but also across a wide range of domains, including workplace safety, employee benefits, pollution control, historical preservation, antitrust, and consumer protection law.

Thus, the "legalization hypothesis" posits that although large bureaucratic organizations still seek to influence public law, they have also come to internalize a substantial amount of lawlike rule making within their own polity structures and within the polity structures of their surrounding fields. Although the legalization of organizational life was already under way when Galanter first published "Why the 'Haves' Come Out Ahead," this process appears to have accelerated dramatically over the ensuing quarter century as organizations have responded to-and constructedan ever more complex legal environment. As a result, organizations increasingly manage both internal and external relations through facially neutral universalistic rules and rationalized formal procedures. Internal governance now centers on the establishment of a complex citizenship system of rights, privileges, entitlements, and duties, and external governance now centers on the establishment of an elaborate web of regulations, contracts, norms, and professions. Together, these developments appear to be transforming private lawmaking from an occasional managerial expedient into a core organizational function. 


\section{The ADR Hypothesis}

When "Why the 'Haves' Come Out Ahead" first appeared in 1974, the term alternative dispute resolution (ADR) was not part of the common lexicon (Galanter 1999; Plapinger 1999). Certainly, many organizations engaged in informal dispute handling of various kinds (consider, for example, the role of the hospital ombudsperson, the church pastor, or even the school principal), but the intentional construction of private disputing forums was a marginal and idiosyncratic activity, embraced by only a few organizational fields. In the years since 1974, however, an "ADR movement" 6 has begun to take shape among legal and other professionals, with proponents advocating a plethora of nonjudicial dispute resolution techniques, including most notably various flavors of mediation and arbitration. Propelled by this movement, systematic private dispute processing appears to be gaining prominence as a way for organizational repeat players to structure their future transactions. ${ }^{7}$ Just as legalization allows organizations to internalize lawlike control over their routine activities and operations, ADR-for both inter- and intraorganizational disputes-allows organizations to internalize lawlike control over their "problem cases."

The ADR movement has developed largely as a critique of overly formalistic court adjudication and of the "liberal legal model" of public rights more generally. In place of public lawsuits, ADR allows disputing parties to negotiate their own private solutions to their disagreements, generally with a trained disputeresolution professional serving as a "neutral" facilitator. Proponents suggest that such structured informality can resolve disputes more responsively and more durably than traditional litigation, can empower disputants to recognize and assert their needs while simultaneously honoring the needs of others, and can even help to preserve and build community (Fisher \& Ury 1981; Menkel-Meadow 1984; Moore 1986; Westin \& Feliu 1988; Bush 1989; Rosenberg 1991; Bush \& Folger 1994; Lande 1998; cf. Edelman \& Cahill 1998). Further, at a more pragmatic level, the

6 Here and below, we use the term movement loosely, to identify a suggestive preliminary trend or tendency coupled with a set of justificatory rational myths and a significant constituency. A movement in this sense is partly an empirical pattern, partly an ideological program, and partly a political mobilization.

7 Even in 1974, Galanter noted that when repeat players engage in ongoing dealings with one another, they frequently set up private governance structures to handle disputes (1974:110-11). At the time, however, Galanter attributed such private dispute handling to rational calculations of the expense and disruptiveness of litigation; ADR was, in a sense, organic to the community of repeat players. Today, the tendency toward private dispute resolution is perhaps as much a function of a general social climate that favors and institutionalizes ADR per se as it is a function of calculated efforts by individual actors to circumvent litigation. Carried forward by a substantial social movement, the privatization of interfirm conflict has become an organizing principal of the broader institutional order, promoted evangelically even where it may not be supported indigenously. 
ADR movement also promises a relatively inexpensive and efficient alternative to the delay, cost, risk, and bad publicity of litigation (Lande 1998).

Although many of these themes have deep roots in sociolegal thought, the ADR movement itself only emerged in earnest in the mid-1970s, when a series of convocations and experiments began to stir interest and mobilize expertise. Among the most influential of these early events was the Pound Conference, a 1976 meeting of judges, attorneys, and law professors in St. Paul, Minnesota. The conference elicited calls for a new multimethod "dispute resolution center," designed to replace the traditional courthouse (Kaye 1996). The idea of the minitrial followed soon thereafter and was first implemented in 1977 (Plapinger 1999). Two years later, 12 corporate counsel joined together to found the Center for Public Resources (CPR) Institute for Dispute Resolution, a standing body dedicated to promoting ADR both for interorganizational business disputes and also for intraorganizational disputes between employers and their employees (Westin \& Feliu 1988).

From these beginnings, the ADR movement has built a solid base of support among practitioners and policy makers alike. $\mathrm{Nu}$ merous books and articles have touted ADR as the cure for various organizational ills (e.g. Westin \& Feliu 1988; Ewing 1989), and professional management journals have brimmed with ADR testimonials (Edelman, Uggen, \& Erlanger 1999).$^{8}$ Federal law and policy have reinforced such arguments. The Equal Employment Opportunity Commission (EEOC) and many state workers' compensation boards now encourage the use of ADR in employer-employee disputes (Lipsky \& Seeber 1998), and both the 1990 Americans with Disabilities Act and the 1991 Civil Rights Act include explicit provisions promoting ADR for a wide range of discrimination claims. The judiciary, for its part, has generally followed suit-as evidenced, for example, by the U.S. Supreme Court's 1991 Gilmer ruling (Gilmer v. Interstate/Johnson Lane Corp. 1991), which upheld the validity of mandatory arbitration clauses, even though such clauses may prevent parties from vindicating significant statutory rights (Lipsky \& Seeber 1998). Indeed, the use of ADR has even gained substantial currency within the courts themselves. As early as 1980, 10 states and one federal district were experimenting with ADR, and by 1996, nearly half of all state and federal jurisdictions were operating ADR programs of some kind (Reuben 1996, 1997).

In response to these developments, the organizational world has come since 1974 to embrace $\mathrm{ADR}$ for a wide variety of both

8 ADR has also attracted growing attention among academics and business journalists. A search for the term alternative dispute resolution in the ABI/INFORM database (a comprehensive online database of business periodicals) yields only two references in the decade from 1970 to 1980 , compared with 316 in the 1994-1995 biennium alone. 
inter- and intraorganizational matters. In a recent survey of 70 outside counsel, 58 inside counsel and 50 senior corporate executives in three states, Lande (1998:15) found that $90 \%$ of outside counsel, $84 \%$ of inside counsel, and $39 \%$ of senior executives reported having participated in an ADR proceeding as a partisan at least once. Over $60 \%$ of attorneys (both outside and inside) and $12 \%$ of executives reported having participated in ADR four times or more, and in some jurisdictions, the percentages were even higher (Lande 1995:83). Similarly, Lipsky and Seeber (1998:137) report that $88 \%$ of the 1,000 largest U.S. corporations use mediation or arbitration on a regular basis, particularly in commercial and employment cases. ${ }^{9}$

For interorganizational disputing, the public court system remains an important forum, but it no longer holds an unquestioned monopoly (Lande 1995). Although rates of traditional business litigation have risen since 1974 (Galanter \& Rogers 1991:3-17), ADR appears to have gained substantial legitimacy as well, to the point where many executives reportedly view extralegal dispute processing not only as a viable alternative to formal lawsuits, but actually as a preferable alternative, especially when conflicts arise in the context of ongoing business relations (ibid., pp. 18-20; Lande 1995). ${ }^{10}$ Thus, for example, Lande reports that almost $80 \%$ of senior executives express greater satisfaction with ADR than with litigation (ibid., p. 139), and a similar percentage believe that ADR would be appropriate in half or more of all business lawsuits (ibid., pp. 166-67). Further, over $80 \%$ indicate that ADR helps to preserve business relationships (ibid., p. 319), and over $90 \%$ believe that ADR is more sensitive than litigation "to the needs and practices of particular business communities" (ibid., p. 321).

Although such attitudes suggest widespread managerial support for $\mathrm{ADR}$, actual shifts in behavior are harder to quantify, because the research literature offers few consistent longitudinal measures of organizational disputing; nonetheless, several indirect indicators suggest that interorganizational ADR has blossomed in recent years. One such indicator is the growing willingness of corporations to sign the Center for Public Resources' (CPR) "ADR pledge," 11 expressing a commitment to resolve in-

9 These authors report that ADR is also fairly widely used in personal injury and product liability disputes but is less popular in matters of corporate finance.

10 There is good reason to believe that businesses with ongoing relationships have long favored extralegal dispute resolution (see, e.g., Macaulay 1963); in the past, however, such resolution has generally taken the form of direct negotiation or informal community pressure rather than organized $\mathrm{ADR}$.

11 The CPR pledge reads, in part, "In the event of a business dispute between our corporation and another corporation which has made or will then make a similar statement, we are prepared to explore with that other party, resolution of the dispute through negotiation or ADR techniques, before resorting to full-scale litigation" (quoted in Galanter \& Rogers 1991:19). 
terorganizational disagreements through ADR rather than litigation. From an initial 46 signatories in 1984, the roster of endorsements has expanded dramatically, to almost 500 by 1990 and over 4,000 by 1999 (Galanter \& Rogers 1991:19; CPR Institute for Dispute Resolution 1999). A second, somewhat more concrete indicator is the commercial caseload of the American Arbitration Association, which more than doubled between 1975 and 1988 (Galanter \& Rogers 1991:Figure 5). ${ }^{12}$ During this period, the number of private ADR providers also increased substantially, further adding to the sense that public courthouses are no longer the only "natural" venues for the handling of interorganizational disputes (ibid., p. 19).

A similar pattern seems to be emerging for intraorganizational disputing as well. Here, ADR has served as the model for various types of "internal dispute resolution" (IDR)-informal in-house alternatives to public lawsuits (Edelman et al. 1993). ${ }^{13}$ Although longitudinal evidence on intraorganizational disputing remains sparse, several recent studies suggest that IDR in general is on the rise and that ADR-like forms of IDR have become quite common. Perhaps the clearest indicator of the growing prevalence of IDR is the spread of employee grievance procedures beyond traditionally unionized industries. Using two separate samples of firms throughout the economy, both Sutton et al. (1994) and Edelman, Uggen, and Erlanger (1999) report that the proportion of organizations with internal grievance procedures climbed sharply during the 1970 s and continued to rise more gradually thereafter. Further, the ADR movement appears to have fostered particular interest in forms of IDR that emphasize active disputant participation, that incorporate mediation or other types of dialogic negotiation, and that focus less on public rights than on private psychological issues (Westin \& Feliu 1988;

12 The caseload of the federal courts also rose substantially during this time (Galanter \& Rogers 1991:5 ff.), suggesting that the growth of ADR measured in proportion to all business disputing may not be quite as great as the growth measured in absolute numbers. The available data, however, are not comprehensive enough to allow a calculation of precise ratios, and in any case, absolute numbers may actually be a more appropriate indicator of the degree to which $\mathrm{ADR}$ has become a familiar, if not predominant, feature of the disputing landscape.

13 In many ways, IDR actually preceded (and to some degree presaged) the ADR movement of the 1970s. Disputes involving union workers have been resolved through grievance arbitration ever since the labor movement of the 1930s (Slichter 1941), and even in nonunion settings, personnel professionals have long promoted internal mediation and arbitration as ways of forestalling unionization and encouraging smooth employment relations (Jacoby 1985). Moreover, from the 1960s onward, the civil rights movement, like the labor movement, motivated significant interest in IDR, as employers sought both to incorporate publicly legitimated models of just treatment and also to discourage discrimination-related lawsuits (Edelman 1990; Sutton et al, 1994). This history notwithstanding, however, the ADR movement appears to have engendered significant changes in both the prevalence and the character of IDR in recent years, as discussed in the following pages. 
Edelman et al. 1993). ${ }^{14}$ In reflection of this, a 1995 General Accounting Office survey of 1,500 businesses found that $88.7 \%$ of private-sector companies with 100 or more employees were using some form of $\mathrm{ADR}$ for intraorganizational disputes, with mediation $(47 \%)$ and arbitration $(10 \%)$ being among the most common choices (General Accounting Office 1995).

Overall, then, the "ADR hypothesis" postulates that although large bureaucratic organizations still make heavy use of the public court system, they have also constructed a growing number of private disputing forums within their own organizational boundaries and within their industries, business communities, and fields. Both intra- and interorganizationally, the spread of ADR promotes informal dispute resolution based on privately negotiated norms and procedures at the same time that it curtails the formal enunciation, vindication, and enforcement of publicly mandated legal rights. Thus, like legalization, the ADR movement allows organizations (and organizational fields) to internalize a core legal function-in this case, dispute processing. To be sure, ADR also rejects some aspects of formal legalism, and in this sense, the legalization hypothesis and the ADR hypothesis may appear to be at odds. In the organizational context, however, the two movements stand for fundamentally similar things: legalization reflects a belief that rule-compliant fairness should be an attribute of private organizations as well as of public institutions, and ADR reflects a belief that rule-compliant fairness should be achieved in private forums, without the intrusion of public authorities. ${ }^{15}$ Together, the two outlooks suggest that organizations can become their own courts and can create, embody, and implement rule-compliant fairness on their own behalf.

\section{The In-House Counsel Hypothesis}

In 1974, Galanter argued that repeat players benefit from low start-up costs and economies of scale, because repeat players can hire lawyers on retainer and can treat legal preparation as a longrun investment. In addition, he noted, repeat players also benefit from greater familiarity with the law, because they can "learn by

14 Even "formal" internal grievance systems, which often mimic aspects of the public courts, are nonetheless considerably more flexible and ADR-like than true litigation. Most such systems operate with minimal rules of evidence, no prehearing discovery, no right to counsel, and no principle of stare decisis.

15 The key to this reconciliation of legalization and ADR is that the ADR movement does not attack the "rule of law" as much as it attacks the linkage between the rule of law and a particular set of public adjudicatory institutions. Whether correctly or not, the ADR movement asserts that, with the help of a third-party facilitator, lay actors can construct their own interpretations of law, and the law thus constructed will be more fair than the formalistic rulings of a passive court reacting to a stilted confrontation between professional adversaries. Thus, ADR embraces the principle of rule-compliant fairness at the same time that it rejects the specific rules of traditional litigation. 
doing" in the course of their frequent contacts with the legal system. In recent years, several commentators have suggested that these previously distinct advantages of preparedness and expertise may be merging and intensifying as large bureaucratic organizations build increasingly sophisticated internal legal staffs (Chayes \& Chayes 1985; Rosen 1989; Galanter \& Rogers 1991:22-25; Nelson 1994; Nelson et al. 1997). Thus, a third potentially significant form of legal internalization may be the ascendance-in numbers, in status, and in influence-of the inhouse counsel's office. ${ }^{16}$

Rather than simply keeping independent law firms on retainer, large bureaucratic organizations seem increasingly reliant on full-time salaried employees for the provision of general legal services. By some accounts, over two-thirds of the legal budgets of America's largest corporations are now spent on in-house lawyers who work in areas as diverse as real estate, antitrust, employment, intellectual property, and regulatory law (Chayes \& Chayes 1985:279; Galanter \& Rogers 1991:24). ${ }^{17}$ Although commentators disagree over whether the population of in-house lawyers has expanded faster than the legal profession as a whole (see Rosen 1989:482 n. 7; Nelson 1994:370, 391), the absolute number of such attorneys has clearly increased substantially since the early 1970 s, with the nationwide total approximately doubling in the 15 years from 1975 to 1990 (estimated from figures reported in Nelson 1994 and Heinz et al. 1998; see also Chayes \& Chayes 1985:277 n. 1; Curran 1985; Galanter \& Rogers 1991:22-25). Inhouse legal staffs seem to be growing on a firm-by-firm basis as well. In a replication of Heinz and Laumann's classic 1982 study of the Chicago bar, Heinz et al. (1998) found that the average corporate legal department had ballooned from 17 attorneys in 1975 to 55 attorneys in $1995 .{ }^{18}$ Although nationwide evidence is too sketchy to allow unequivocal cross-time comparisons, Galanter and Rogers (1991:22-23) estimate that the proportion of manufacturing companies with in-house legal departments rose from $47 \%$ in 1959 to $59 \%$ in 1987 and that the total number of in-house lawyers increased across virtually every industrial sector. These trends seem to be particularly marked among Fortune 500

16 In this essay, we use the terms in-house counsel's office, corporate legal department, and corporate legal staff to refer generically to all attorneys who practice law as salaried employees of nonlegal organizations. Although recent research suggests that there may be important differences between lawyers who work in a centralized legal department and those who hold positions elsewhere in the organizational hierarchy (Rosen 1989; Nelson et al. 1997), few statistical analyses differentiate between these two categories, and for the most part, this distinction lies beyond the scope of our analysis. Our general argument, we believe, applies to centralized and decentralized legal staffs alike, although in practice a few of the particulars may vary.

17 Litigation is the one area of practice that continues to be dominated by outside law firms, but even here, the role of inside counsel has grown substantially (see below).

18 Government legal staffs experienced an even larger increase, rising from an average of 64 attorneys per office in 1975 to 399 per office in 1995. 
companies, which employ roughly $50 \%$ of all attorneys working in private industry (Curran 1985:19).

As these changes unfold, the decision to join a corporate legal staff-to "go in-house"-may be losing its pejorative implications within the legal profession (see, e.g., Chayes \& Chayes 1985:277; Rosen 1989:479). Financially, inside counsel have kept roughly abreast of private practice attorneys in the years since 1974, with earnings growth lagging slightly behind large-firm lawyers but easily outpacing solo practitioners. ${ }^{19}$ Indeed, even during the economic slowdown of the early 1990s when cost-cutting and downsizing were sweeping corporate America, in-house counsel salaries were rising at close to a $6 \%$ annual rate (Becker 1992). Moreover, with many young lawyers perceiving that workloads are lighter and autonomy greater in corporate legal departments than in independent "megalaw" firms (cf. American Bar Association 1991; Heinz et al. 1998:744), in-house counsel offices are no longer seen merely as refuges for attorneys who lack the acumen to earn partnership outside (Chayes \& Chayes 1985:277, 293; Gilson \& Mnookin 1985:382). Consequently, although reliable data on hiring trends are hard to find, most observers agree that the ability of large bureaucratic organizations to recruit and retain highly credentialed, experienced legal talent has risen substantially in recent years (Strasser 1985; Rosen 1989:504; Becker 1992).

Along with their increased size and status, corporate legal staffs appear to have gained new responsibilities as well. Although few studies have gathered detailed historical evidence on the activities of this segment of the bar, most observers agree that, in the past, the bulk of in-house work amounted to little more than routine ministerial housekeeping (Slovak 1979; Chayes \& Chayes 1985; Spangler 1986). In contrast, today's inhouse lawyers increasingly style themselves as active "law managers," buffering the corporation from external legal demands and bridging to outside service providers (Chayes \& Chayes 1985:289 ff.; Rosen 1989:545; cf. Scott 1992:194). During pretrial discovery, for example, inside attorneys now play an assertive, autonomous role in screening corporate documents and in negotiating with outside counsel over the scope of the company's disclosures (see, generally, Fordham Law Review 1998).

In such interactions with outside attorneys, in-house counsel draw strength not only from their coequal claims to legal exper-

19 Nelson (1994:394-95) reports that in 1975, the average starting in-house lawyer earned $98 \%$ as much as the average starting law firm associate, $32 \%$ as much as the average large firm partner, and $97 \%$ as much as the average solo practitioner. In 1990, the comparable percentages were $82 \%, 32 \%$, and $111 \%$, respectively. According to a recent American Bar Association survey, $77 \%$ of in-house counsel reported 1990 income in excess of $\$ 55,000$, compared with only $58 \%$ of private practitioners; $36 \%$ of in-house counsel topped $\$ 100,000$, whereas only $28 \%$ of private practitioners reached this level (American Bar Association 1991). 
tise but also from their extensive discretion over the selection of outside law firms for future business (Chayes \& Chayes 1985:292; Nelson 1994:355). Legal work is increasingly put out to bids, with the inside counsel's office presiding over the "beauty pageants" that choose among potential representatives. At the extreme, a number of large corporations have even moved toward a subcontractor model in which the inside counsel's office "unbundles" legal services by, for example, assigning paralegal tasks to one outside firm and drafting tasks to another (Suchman 1998:857). For obvious reasons, these new approaches to the procurement and supervision of legal services substantially expand the role and influence of staff attorneys, especially with respect to their colleagues in private practice.

Relatively little systematic research has explored the forces driving this emerging "in-house counsel movement" (Rosen 1989), but most observers attribute the apparent shifts to at least three factors. First, the growth of in-house counsel offices responds, in part, to an increase in the cost of outside legal representation. As legal fees rise (both on a per-case basis and as a share of overall corporate budgets), expanded internal legal staffs can (1) absorb and routinize some tasks that might otherwise be performed at premium prices outside and (2) manage and rationalize the purchase of any legal services that the organization continues to seek externally (Chayes \& Chayes 1985:297; Strasser 1985; Becker 1992; Nelson 1994:355). Second, in-house counsel offices may also be expanding in response to the increasing complexity and intrusiveness of the general legal environment. Organizations theory teaches that organizational structures tend to mirror environmental variety (Pondy \& Mitroff 1979:7), and as legal regulations and liabilities proliferate in areas such as employment, labor relations, health and safety, antitrust, pollution abatement, intellectual property, and international trade, organizations are likely to respond by creating internal structures-staffed by lawyers-to manage these new external contingencies (Chayes \& Chayes 1985:284-85; Nelson 1994:349-50). Finally, the expansion of in-house legal staffs may both reflect and reinforce the larger legalization trends described above. As organizations construct internal lawlike polities, inside counsel often play central roles in staffing the positions and drafting the rules that constitute these "corporate citizenship" regimes (Chayes \& Chayes 1985:285-86; CroninHarris 1997). ${ }^{20}$

20 Of course, these three dynamics are often related. Outside legal expenses may have risen, in part, due to the increasing scope, complexity, and criticality of organizations' legal exposure. Similarly, legalization tends to proceed fastest where external regulatory efforts are most salient (cf. Edelman 1990). And legalization, in turn, may spur the proliferation of in-house attorneys precisely because rising legal fees militate against the hiring of outside specialists to preside over increasingly routinized internal legal orders. 
Whatever the origins of the in-house counsel transition, the attendant internalization of professional expertise holds the potential to subtly alter the character of corporations as legal actors. Instead of being lay consumers of legal services-who, as Galanter notes, know the legal system primarily through their pragmatic contacts with it-organizations are increasingly becoming "corporate legal professionals" in their own right. Where inside attorneys once served merely as glorified notaries or as passive conduits between the corporation and its outside law firm (Slovak 1979; Spangler 1986), the modern in-house counsel's office now stands as the highly professionalized face that the corporation shows to the legal world (Nelson et al. 1997; Chayes \& Chayes 1985). In some areas, in-house counsel supplant outside law firms entirely, while in others, they merely supervise outside services. In either mode, however, expanded legal staffs allow corporations to confront the external legal system with more information, more authority, and more initiative than ever before.

Thus, the "in-house counsel hypothesis" posits that although large bureaucratic organizations still seek external legal representation when the economics (or occasionally the politics) of the situation demands, they no longer encounter their outside lawyers from the position of lay clients. Rather, many if not most large organizations now operate as fully empowered legal experts, negotiating over the scope and terms of any outside representation and often dictating the strategies that their legal subcontractors will pursue. Further, this internalization of expertise meshes with the two internalization hypotheses offered above: inhouse counsel generally play a central role in drafting the formalized regulatory compliance policies that promote legalization (Rosen 1989), and they often make the initial determination of which disputes the organization will litigate and which it will submit to ADR (Chayes \& Chayes 1985:297; Cronin-Harris 1997). As Nelson et al. (1997:27-28) note, the rise of in-house counsel blurs the distinction between doing business and doing law (see also Chayes \& Chayes 1985:298). For the members of this ascendant segment of the bar, and for the organizations that employ them, it is sometimes hard to say exactly where legal rationality leaves off and bureaucratic rationality begins.

\section{The Private Security Hypothesis}

The fourth apparent form of internalization of law since 1974 is the rise-or, more correctly, the reemergence-of corporate private security. ${ }^{21}$ Theory and research on this development re-

21 In this article, we use the terms private security and private policing interchangeably to refer to the provision of in-house security and enforcement services by an organization's employees or subcontractors. Elsewhere in the literature, private policing often denotes a broader phenomenon, encompassing not only in-house police services but also such nongovernmental law enforcement activities as volunteer block watches and vigi- 
main sparse (Marx 1987:188; but see Shearing \& Stenning 1981, 1983, 1987; Cunningham et al. 1990; Davis et al. 1991); there are, however, sound grounds for believing that just as large bureaucratic organizations may be internalizing legal governance, dispute resolution, and expertise, they may also be internalizing enforcement.

Private policing is not a new phenomenon, of course. Historically, private or entrepreneurial security forces were the norm and not the exception throughout much of the industrial revolution (Traub 1996; cf. Spitzer \& Scull 1977a). U.S. labor history, for example, offers numerous instances in which private enforcers, such as the Pinkerton Agency and the Ford Service, imposed industrial "order" at the behest of large corporations (Morn 1982; Weiss 1987). In the early 1900 s, however, the emergence of modern, bureaucratized public law enforcement agencies pushed private policing into abeyance. Although many organizations continued to maintain modest security forces, most such forces engaged primarily in routine guard duty, with only limited surveillance, investigative, or punitive responsibilities. For active policing, public law enforcers were generally seen as both more capable and more legitimate than their private counterparts.

The available research on private security suggests that this situation may now be changing. As budget constraints and political agendas channel the efforts of public law enforcers away from corporate settings, private security forces have begun to reemerge as active agents of social control (Spitzer \& Scull 1977b:265; Cunningham et al. 1990:236). Few hard statistics are available, but recent reports suggest that private police may outnumber public police in the United States by as much as 3:1, up from a ratio of 0.7:1 in 1970 and 1.7:1 in 1980 (Economist 1997; Cunningham et al. 1990:229; Chaiken \& Chaiken 1987:5; Marx 1987:174). If accurate, these figures imply a total private force of roughly two million individuals, double the force size of 1980 (Bureau of Justice Statistics 1999; Cunningham et al. 1990:229; see also Davis et al. 1991:396). Expenditure measures show a similar pattern of growth. According to most estimates, private security spending has risen by an order of magnitude in the past 25 years, from $\$ 6$ billion in 1974 to somewhere between $\$ 35$ and $\$ 90$ billion in the late 1990s (Cunningham et al. 1990:238; Traub 1996; Economist 1997); by comparison, public law enforcement spending has risen relatively modestly, from $\$ 11$ billion in 1975 to roughly $\$ 40$ billion in 1997 (Cunningham et al. 1990:238; Economist 1997)..$^{22}$ Further, private security efforts appear to ex-

lante justice; these additional aspects of private policing, however, lie well beyond the scope of our analysis here.

22 In inflation-adjusted 1998 dollars, private policing expenditures in 1974 totaled approximately $\$ 20$ billion, whereas public policing expenditures totaled slightly over $\$ 36$ billion. 
tend broadly across a variety of economic sectors: One 1990 study estimated private protection expenditures of $\$ 13.4$ billion in manufacturing, $\$ 9.5$ billion in retail, $\$ 4.2$ billion in finance, and $\$ 2.8$ billion apiece in health care and education; even government has participated in the private security boom, with state agencies supplementing the $\$ 30$ billion public police budget with an additional $\$ 10$ billion of spending on "private" protection of their own (Cunningham et al. 1990:198, 238; cf. Cunningham 1980).

Alongside their traditional guard and patrol responsibilities, corporate security personnel have increasingly assumed surveillance, detective, and undercover duties as well (Traub 1996), and private law enforcement now plays a significant role in arenas as diverse as shoplifting, embezzlement, industrial espionage, and substance abuse. Since the early 1980s, drug testing programs have become a major focus of expansion. The proportion of Fortune 500 companies maintaining such programs reportedly climbed from 18\% in 1985 (Ackerman 1985) to $40 \%$ in 1991 (Hartwell et al. 1996) and 78\% in 1995 (May 1999). Electronic surveillance is also common: A recent American Management Association study found that $63 \%$ of surveyed organizations practice some form of electronic monitoring, including $34 \%$ that videotape workspaces to counter theft and sabotage, $16 \%$ that videotape employee performance, $15 \%$ that store and review electronic mail, $14 \%$ that store and review computer files, $10 \%$ that tape and review telephone conversations, and $5 \%$ that tape and review voice mail (American Management Association 1997). In addition, as concerns about personal safety have risen, private security forces have assumed a leading role in designing "safe spaces," such as parking lots configured to minimize the risk of sexual assault (Joh 1999).

To a remarkable extent, as in the case of ADR, legislatures and courts have endorsed and abetted these developments. The retail sector provides a particularly clear example. Under the laws of most states, private security officers enjoy extensive authority to monitor, hold, search, and interrogate suspected shoplifters, with few if any due process constraints (Davis et al. 1991; cf. Traub 1996). "Merchant privilege" statutes have traditionally immunized store police from liability for claims of false arrest, false imprisonment, or unlawful detention (Bishop 1988:68), and courts have generally followed suit, ruling, among other things, that private persons acting without government supervision fall outside the search-and-seizure restrictions of Mapp v. Ohio (1961) and beyond the interrogation restraints of Miranda $v$. Arizona (1966) (Davis et al. 1991:399). ${ }^{23}$ Furthermore, in recent years, many jurisdictions have augmented these private arrest powers

23 As Marx (1987) notes, when public law enforcement agencies work alongside corporate private security forces, these exemptions create the possibility that the govern- 
with "civil recovery" provisions, which give store police the option of recovering monetary damages in lieu of handing the accused over to public authorities for arrest. Although the resulting penalties are civil rather than criminal in character, their dollar value can be quite substantial. Many statutes allow merchants to recover not only the cost of any pilfered merchandise, but also "exemplary" fines or treble damages, legal fees, and even the cost of maintaining store surveillance (ibid., p. 396). Taken as a whole, this legal regime not only gives private organizations the capacity to monitor, investigate, arrest, and indict, but also (in the absence of a right-to-counsel for civil defendants) the effective capacity to try and sentence.

Presumably, the other aspects of legal internalization described above have, if anything, buttressed and accelerated the resurgence of corporate private security. At the turn of the twentieth century, public bureaucratized law enforcement played a crucial role in legitimizing corporate capital. Operating under the banner of the rule of law, public police departments offered a legitimate, ostensibly neutral way for corporate interests to maintain order without appearing excessively instrumental or dictatorial (Traub 1996). At the twentieth century's end, however, the legalization of the workplace has created a quite different situation. As corporate policies and structures become increasingly formal, impersonal, and lawlike, the legitimating mantle of legality is almost as readily available to private security forces as to their public counterparts. Insulated against charges of thuggery, corporations are publicly applauded when they "help the police" by patrolling their own domains.

The private security hypothesis suggests that this shift in climate has combined with a perceived scarcity of public policing capacity to foster the widespread incorporation of active private law enforcement functions into the emerging polities of many large bureaucratic organizations. Although less often noted than the three internalization trends described above, this fourth change is cut from much the same cloth. Admittedly, the movement toward private security is still in its youth; nonetheless, if current patterns continue, the potential impact could be substantial indeed.

\section{The Organization as Court (and Lawmaker, Judge, Counsel, and Cop)}

To the extent that the legalization hypothesis, the ADR hypothesis, the in-house counsel hypothesis, and the private security hypothesis are correct, the internalization of law may subtly

ment may acquire secondhand information obtained through techniques that it would have been enjoined from using itself. 
transform large bureaucratic organizations from being well-endowed players in the legal game (Galanter's repeat players) to being nothing less than the playing field itself. In this section, we consider how these hypothesized changes, to the extent that they are indeed occurring, might transform the relationship between organizations and law. As organizations internalize law, they move beyond the repeat player's traditional role as a disputing party, to act, at varying times and to varying extents, as a legislator, adjudicator, lawyer, and constable.

\section{The Organization as Legislator}

Whereas traditional repeat players must use their strategic advantages to wring favorable rules from public lawmaking authorities, the legalization hypothesis suggests that organizations often act as private legislatures in their own rights, promulgating their own sets of rules and constructing their own internal legal regimes to implement those rules. To a striking extent, the organization as legislature replicates many central features of traditional public legislation; at the same time, however, legalization shifts the locus of lawmaking activity inside the corporate hierarchy, often with substantial consequences.

The similarities between public and organizational legislation are many. Like legislators in the public realm, organizational legislators attempt to read the social environment-including the needs and wishes of their constituents-and to write rules that implement a particular vision of what that environment and those constituents require. At the same time, again like legislators in the public realm, organizational legislators may also pursue less lofty ends, writing rules that are cynically calculated to enhance the author's visibility and to bolster the author's career. For organizational legislatures as for public legislatures (which, of course, are themselves organizations), a common route toward both these ends is to write rules that restate, reinstitutionalize, or in other ways incorporate prevailing public norms (cf. Bohannon 1965). At times, the organization as legislature may consciously pursue social and economic benefits by promulgating rules that symbolize compliance with the norms of public authorities. At other times, the organization as legislature may incorporate public norms less consciously, by adopting "prefabricated" rules that have acquired an institutionalized status within the larger environment-that is, rules that the surrounding organizational field has come to take for granted as the rational, proper, and obvious way to conduct a particular activity. In either case, by mirroring and re-presenting elements of the public legal order, legalization allows organizations to borrow from the legitimacy of established legal principles. For example, organizations routinely adopt grievance procedures as a rational, proper, and obvious response 
to a legal environment that favors fair treatment of employees; they routinely adopt hazardous materials precautions as a rational, proper, and obvious response to laws addressing occupational safety and health; and so on, down the line.

As with public legislatures, some organizations are "pioneers," others are "tinkerers," and still others are "followers" in this rule-making game. Such heterogeneity is likely to be reflected in organizations' motivations for rule adoption, although perhaps in complex ways. Often the earliest adopters of a particular rule are those firms whose cultures feature strong value commitments to the rule's underlying normative agenda. In these "progressive" polities, organizational legislators will have much to gain, both in personal satisfaction and in public prestige, from the enactment of rules that symbolically declare the sanctity of locally prevailing customs (cf. Gusfield 1963). Thus, for example, a firm that prides itself on being "disability friendly" might proclaim this corporate identity by proactively legislating certain workplace accommodations, even in the absence of any external pressures to do so (Scheid \& Suchman 1998). Although such principled pioneers are generally few in number, they often generate the patterns and premises from which other organizations subsequently proceed. Typically, if the ethics of these pioneers win favor in the larger environment, a second wave of more cautious tinkering will follow, as less committed organizations strategically assemble limited subsets of the new rules, in an effort to preserve the legitimating symbolism of the pioneering enactments while facilitating a substantial degree of decoupling between formal structure and informal practice (Edelman 1992). For example, in an effort to insulate themselves from employment discrimination lawsuits, firms may legislate extensive formal evaluation and grievance procedures, while doing little to challenge informal managerial biases and prerogatives (ibid.; Scheid \& Suchman 1998). Finally, as standardized models of acceptable compliance begin to emerge, a third wave of more reactive followers may simply mimic the behavior of other organizations in the field, accepting (and implicitly reinforcing) the presumed rationality of the prevailing regime.

Whether pioneering, strategic, or merely imitative, legalization can be a mixed blessing, both restricting and enhancing organizational power, simultaneously. As several commentators have noted, legalization tends to constrain traditional managerial prerogatives by infusing external legal values into internal organizational practices (see e.g., Selznick 1969; Sitkin \& Bies 1994). Irrespective of the reasons for legalization or the intentions of top administrators, lawlike rules and structures often subtly shift the organizational agenda. Practices designed to promote (or merely to symbolize) workplace safety, or equal employment opportunity, or environmental protection tend to expand the 
"rights consciousness" of organizational stakeholders, encouraging demands for ever more substantive reforms; moreover, the officials who implement these practices tend to become internal advocates for the values that the practices symbolize, giving the law an indirect voice in organizational decisionmaking (Edelman et al. 1991; Edelman \& Petterson 1999). Thus, organizational rulemaking can create important new political claims and allegiances that skillful players can deploy in subsequent debates (cf. Scheingold 1974). Despite the rhetorical appeal of calls to subject organizations to the rule of law, at a practical level these internal political resources may matter far more than external legal mandates. Because the vast majority of organizational problems do not result in lawsuits, legalized bureaucratic routines may provide society's best hope for protecting the rights and interests of otherwise disempowered organizational citizens (cf. Heimer \& Staffen 1998).

Nonetheless, attention to legalization as restraint should not obscure the fact that internalized lawlike rulemaking also significantly alters the locus of the legal game, often to the organization's great advantage. In 1974, Galanter argued that repeat players can often "play for rules" by using lobbying and strategic litigation to shape the legal principles that govern future transactions (1974:100-3). Although such tactics continue to dominate many organizations' playbooks, the rise of organizations as legislatures raises a second potent possibility. Sometimes, rather than playing for rules alone, organizations can "play for literary license" by incorporating legal standards and rewriting them internally.

The resulting advantages can take several forms. In some cases, organizations can actually legislate legislation away-as they do, for example, when they adopt standard-form contracts that contain mandatory arbitration provisions. By substituting private dispute resolution for the traditional right to sue and by requiring employees and customers to agree to these provisions, organizations explicitly remove certain matters from the purview of the public courts. Even when private legislation cannot formally eliminate public legislation from the picture, however, "house law" may nonetheless effectively trump "state law" in many contexts. This situation is particularly true for employee relations, an area in which house law's more immediate impact on organizational legal culture makes private legislation the primary legal force shaping the emergence and transformation of workplace disputes (Fuller et al. 2000; cf. Felstiner et al. 1980). Finally, and most profoundly, when standardized internal legislation is aggregated across entire organizational fields, it can actually colonize state law itself by effectively redefining what is seen as "normal," "reasonable," "rational," and "compliant." Far from being mere private perturbations, which aggressive public en- 
forcement could readily correct, internal rephrasings of legal rules often profoundly reconstitute external legality itself, as courts look to the organizational world for viable models of social responsibility and sound management practice. Edelman, Uggen, and Erlanger (1999) report, for example, that internal grievance procedures have become such effective symbols of attention to due process that public courts, which once saw internal reviews as legally irrelevant prologues to litigation, now increasingly treat the existence of such in-house proceedings as a central consideration in determining whether to hold an employer liable for workplace discrimination.

Taken as a whole, then, the legalization of large bureaucracies converts organizational decisionmakers into private legislators. This shift, in turn, substantially enhances the ability of organizational repeat players to structure future transactions and to establish the rules under which breakdowns in those transactions will be resolved. Although organizational legislation often responds to public norms, it does so through the filters of organizational culture, organizational politics, and organizational interests. Not only can the resulting private laws displace public laws from organizations' internal polities, but also these private laws can occasionally reconstruct external polities in the organizational world's own image. These advantages go beyond simply playing for individual rules; they make organizations the authors, editors, and publishers of the rulebook itself.

\section{The Organization as Adjudicator}

If the legalization hypothesis implies that organizations are increasingly becoming lawmakers, the ADR hypothesis implies that organizations are increasingly becoming judges and courts-or, more broadly, dispute processors. Whereas an organization might once have simply referred problem cases to public legal institutions for resolution, ADR procedures instead allow it to resolve many matters in situ, in private forums that are, themselves, organizational subunits. ${ }^{24}$ Of course, the organization as court is a rather strange adjudicatory arena, in that some organizational employees (usually line managers and workers) appear as first-party disputants, while others (usually personnel officers) appear as third-party "neutrals," and still others (usually members of the legal staff) appear as system designers and administra-

24 Interorganizational ADR rarely takes place entirely within a subunit of either disputant organization; rather, it generally occurs in a free-standing entity within the larger organizational field or in a subunit of a field-level institution such as an industry association or a leadership council. For the sake of brevity, our discussion focuses primarily on the intraorganizational context (that is, on IDR), because this form of dispute processing most clearly illustrates the implications of the organization as court. Nonetheless, because field-level interorganizational disputing forums are private organizational creations too, much of our analysis should apply to them as well. 
tors. Thus, the best intentions of individual officials notwithstanding, organizational dispute processing forums are rarely level ground.

Because different organizational forums serve different organizational purposes, dispute processing structures vary widely, from formalized, courtlike regimes to much more informal, flexible alternatives. At the courtlike end of the continuum, some formal grievance structures resemble entire judicial systems, with explicit fact-finding procedures, decision standards, and opportunities to appeal up the managerial hierarchy. ${ }^{25}$ Although disputants generally retain the right to remove their claims to the public legal system, external courts will, in practice, often defer to the results of internal hearings and will dismiss the claims of any plaintiffs who have failed to exhaust their in-house remedies (Edelman, Uggen, \& Erlanger 1999). At the opposite, informal end of the continuum lie "open-door policies," in which a senior official makes himself or herself available to address disputes at any level of the organization. Holding plenary power to act as investigator, advocate, and adjudicator all in one, the open-door officer usually serves as the sole arbiter, with no explicit provision for appeal. External legal authorities may be somewhat less likely to defer to such informal decisions, if any grievances actually make it to court; when coupled with mandatory arbitration provisions in disputants' contracts, however, open-door systems can maintain much of the binding authority of formal grievance regimes while eliminating many of the procedural safeguards and constraints. Finally, between these two poles, some organizational forums resemble mediation, with a third-party facilitator easing negotiations without directly imposing any particular resolution. Although ostensibly neutral, such facilitators generally either maintain ongoing business ties with the organization or are themselves members of management, and as a result, both the impartiality and the nondirectiveness of their interventions are open to question. Thus, although mediation-like forums may provide excellent therapeutic devices for ventilating and defusing frustrations (cf. Lind \& Tyler 1988), they rarely pose any greater threat to managerial authority than do formal grievance procedures or informal open-door policies. As a general proposition, the more closely an internal proceeding resembles the public courts, the more thoroughly it will insulate organizational rulings from external scrutiny; even the least formal and least legalistic versions of IDR, however, have the potential to make in-

25 Even the most formal organizational grievance systems are far less formal than the public courts, with organizations generally offering few if any rules about evidence, representation, or other aspects of due process. Indeed, because organizational adjudicators frequently conduct their own investigations, many in-house grievance procedures ultimately look more like arbitration than like adversary litigation. 
house forums the first and last venues for a large number of disputes.

There are, of course, many ways in which ADR can benefit "have nots," both within and around organizations. If ADR proponents are correct, informal dispute resolution allows organizations to handle a much broader set of problems, and to do so more quickly and economically, than traditional litigation (Westin \& Feliu 1988). Such efficiencies have particular value for "have not" disputants, who can rarely afford or endure protracted lawsuits. Further, Edelman et al. (1993) report that internal complaint handlers generally want to resolve all complaintseven those complaints with little legal basis-so as to maintain good morale and smooth working relations. Thus, aggrieved parties who lack legally cognizable claims may find solutions in IDR where they would find none in law. ADR forums such as mediation or arbitration may help "have nots" outside organizations as well, when those claimants possess too little clout to prevail in court. Environmental groups who enter into mediation with a large polluter, for example, may be able to achieve a negotiated resolution that exceeds their strict legal entitlements (Edelman \& Cahill 1998). Perhaps most important, internal adjudication may also benefit "have nots" indirectly by providing a channel for legal values to enter organizational culture. Thus, similar to internal rule-making, internal adjudication may help to institutionalize legal ideals within organizations and organizational fields by raising the legal consciousness of employers and employees alike (cf. Selznick 1969).

At the same time, however, internalized adjudication also has an opposite potential to increase the power of organizational "haves" vis-à-vis the "have nots." In particular, when lawlike disputing moves in-house, the meaning of a "neutral" forum becomes muddy, indeed. In theory, legalization may reframe the organization as a liberal polity, complete with well-institutionalized citizenship rights and formal due process protections; but in practice, the organization nonetheless remains a bureaucratic hierarchy, and the power and authority patterns of that hierarchy inevitably define the relationships between the parties and the court. Not infrequently, a worker complainant will face a manager respondent before a "judge" who is also a member of the organization's management team. Thus, irrespective of their formal roles within the disputing arena, the judge and the respondent share a structural bond that creates a substantial potential for perceptual bias, if not conscious favoritism.

The structural situation becomes even murkier when one considers that, if IDR fails, intraorganizational disputes can potentially progress into the extraorganizational forums of the public legal system. Viewed in this light, the respondent in most intraorganizational cases is really the organization itself, because 
upon removal to the public legal system, the organization would often be vicariously liable for the acts of its agents (Miller $v$. Bank of America 1975). Moreover, were the internal dispute to proceed to a public lawsuit, the internal "judge" would quite likely transmogrify into a key witness for the organization, if not into one of the organization's own lawyers. Thus, the presiding figure in the in-house hearing is an employee and agent of the respondent, whose livelihood and future career depend on other (and higher) employees and agents of the respondent, and who must act in anticipation of potentially becoming a witness for, or a representative of, the respondent. To suggest that such a third party might have structural incentives for protecting the organization's (external) legal position would be to engage in heroic understatement. The informal linkages and mixed motives in organizational IDR "courts" make Blumberg's (1967) criminal courts look like the very picture of impartiality.

Internalized adjudication may also put "have nots" at a disadvantage by depoliticizing and delegalizing conflict, divorcing grievances from principles of law. ADR in general and mediationlike dispute processing in particular tend to emphasize consensus and compromise in place of legal rights, and this tendency is, if anything, accentuated in organizational settings. Organizational complaint handlers, after all, are usually managers, not judges, and their outlooks reflect their training, background, and social milieu. The limited empirical evidence on IDR suggests, for example, that organizational forums tend to recast grievances in ways that downplay legal issues and that focus instead on more typically managerial concerns, such as communication, problem solving, teamwork, and leadership; disputes that originate as rights violations (e.g., safety hazards, discrimination, environmental degradation) are likely to be handled as interpersonal difficulties, administrative problems, or psychological pathologies (Edelman et al. 1993). The "managerialization of law" (Edelman, Fuller, \& Mara-Drita 1999) is, therefore, a natural consequence of processing claims in a setting where managerial problems are the most familiar and the easiest to remedy. Because the underlying bias is fundamentally a structural one, it seems unlikely that organizational courts could be made into more rights-conscious forums simply by staffing them with more judicious personnel. ${ }^{26}$

To further complicate matters, one must recognize that organizations as courts experience few constraining institutional com-

26 The delegalization of dispute resolution is not a purely organizational phenomenon. As the logic of ADR diffuses across an ever wider range of forums, public judges, too, become more likely to consider the psychodynamic underpinnings of disputes and to pursue therapeutic compromise solutions (Merry 1990). Still, however, legal rights remain a centerpiece of the public court system's institutional identity, whereas such rights occupy a distinctly subordinate position in most organizational forums (Edelman \& Cahill 1998). 
mitments to substantive or procedural precedent. As noted in the previous section, the organization itself constructs the substantive rules that guide adjudication, and, hence, the organization acts as legislator and adjudicator together. Equally important, the organization as court also acts as institutional architect, constructing the procedural as well as the substantive rules for hearing disputes. ${ }^{27}$ Thus, managers enjoy broad leeway to tailor particular dispute resolution procedures to particular organizational objectives, drawing on the full range of formal and informal proceedings outlined above.

To be sure, there are some noteworthy limits to this architectural flexibility. In particular, many of the legitimacy benefits that accompany internal due process will disappear if the forum looks too unfair or if the invitation to express grievances seems to be merely a sham. Thus, to some degree, organizational courts reproduce the "problem of legal autonomy" in microcosm: to serve the long-term interests of the elites who support them, organizational courts, like public courts, must maintain at least an appearance of detachment from the short-term interests of those elites in specific cases (cf. Thompson 1975; Balbus 1977). ${ }^{28}$ Also like public courts, organizational courts are constrained by their larger institutional environments. For the public legal system, this environment consists primarily of diffuse social principles and ideals, along with the institutionalized rules of other social sectors; for in-house legal systems, the institutional environment encompasses all these elements, plus, most centrally, the principles, ideals, and institutionalized rules of the public legal system itself. At its core, the entire internalization enterprise rests on the public legal system's willingness to cede jurisdiction to those organizational forums that persuasively mimic their public counterparts. Thus, despite the formal authority that accompanies organizations' newfound legislative, judicial, and administrative powers, most firms strive for (at least the appearance of) fairness, so as to retain their legitimacy as surrogate legal regimes.

Nonetheless, organizational courts enjoy a considerable degree of insulation from outside observation and, hence, a consid-

27 Admittedly, joint responsibility for these legislative, judicial, and architectural functions rarely falls to any one individual (or even to any one organizational subunit), and the claim that "the organization" acts in all these capacities may obscure the potential for intraorganizational segmentation and even confrontation. Nonetheless, although it is important to avoid an excessive personification of large bureaucratic organizations, it is also important to recognize that incentive structures, career ladders, and social networks make it unlikely that internalized legal functions will remain truly distinct from one another over the long run.

28 The problem of legal autonomy implies that legal institutions must appear neutral, even while buttressing prevailing patterns of social inequality. Thus, as Galanter's original arguments suggest, to understand the relationship between law and stratification, one must trace the subtle structural biases that allow the "haves" to come out ahead even in the absence of overt, instrumental manipulation. Presumably, this injunction holds for internal legal structures as well as for their more frequently studied external counterparts. 
erable degree of leeway in institutional design. Internal hearings rarely involve public audiences, reporters, or even lawyers, who could act as external monitors; consequently, the larger society is unlikely to take proactive notice of organizational dispute handling practices. Although disputants generally retain the right to remove their claims to the public legal system, organizations often seek to curtail this right by, for example, requiring that prospective employees (and other contractual partners) agree in advance to forgo future lawsuits and to rely solely on private ADR/IDR should a dispute arise. In theory, procedural shortcomings might still expose organizational decisions to external review, but in practice few one shot disputants will have the inclination or the resources to pursue such outside litigation, especially as long as the disputant's relationship to the organization remains intact. Thus, although internal legal proceedings are not entirely free from external constraint, there is considerable room for slippage, before an internal forum's legitimacy is likely to be put to the test. In this gap, organizations hold court.

\section{The Organization as Lawyer}

Just as organizations appear to have absorbed legal norms through legalization, and legal procedures through ADR, they also appear to have absorbed legal expertise through their inhouse counsel offices. If the in-house counsel hypothesis holds true, then in a very real sense the large bureaucratic organization is no longer a lay actor in the legal arena, any more than it is a passenger on its own vehicle fleet, a licensee of its own research and development efforts, or a bailor in its own warehouses. Rather, organizations are themselves now legal experts, and outside attorneys are merely hired help. On issues where a lay organization might defer to outside counsel, the organization as lawyer will often adopt a more autonomous stance, with inside attorneys relying on their independent legal judgment to filter recommendations to their executive "clients." And on ordinary business issues, where a lay organization might act without prior advice of counsel, the organization as lawyer is much more likely to vet and preengineer its activities, so as to minimize the chances of encountering future legal obstacles. As a result, when the organization as lawyer engages in law-oriented behaviorwhether in external forums or internal ones-it displays a much more coherent and self-conscious legal persona than its lay counterparts. If the prevalence and capacity of in-house counsel are indeed increasing, this change promises to transform the role of the legal profession in the external governance of organizational activity, both for better and for worse.

On one hand, several commentators have noted that the internalization of legal expertise could give the bar an unprece- 
dented level of input into day-to-day organizational decisionmaking (e.g., Chayes \& Chayes 1985; Rosen 1989). Rather than simply rubber-stamping or vetoing nearly final decisions-or, worse yet, defending the organization from liability for decisions long since taken-in-house lawyers could, potentially, insert legal considerations into the earliest stages of the decision process, setting the premises for organizational action in a particularly profound yet subtle way (Chayes \& Chayes 1985:280). The archetype of such in-house legal activity is the practice of "preventive law," whereby staff lawyers construct proactive training, compliance, and monitoring programs, to minimize the organization's potential exposure to lawsuits and regulatory enforcement actions (ibid., p. $284 \mathrm{ff}$.). A similar, albeit less formalized, sort of preemptive framing can occur when staff lawyers participate in routine meetings among executives or when lawyers themselves ascend to positions of direct executive authority. Finally, and most obtrusively, in-house counsel can occasionally embrace a "cop" role (Nelson et al. 1997), setting themselves up as internal guardians of corporate legality and then erecting checkpoints at which they can monitor and, if necessary, quash potentially unethical or illegal initiatives. In all these capacities, the staff lawyer's familiarity, immediacy, and continuity within the organizational hierarchy allow him or her to introduce legal ethics and professional standards into routine decisionmaking, thereby reinforcing and furthering the most "prosocial" aspects of workplace legalization.

On the other hand, however, an increase in internal legal talent may serve not to make organizations more compliant, but rather to make them more skillfully evasive. Compared with the traditional lay organization, the organization as lawyer sees more legal barriers, but it also sees the loopholes through those barriers. It knows more about the constraints of the law, but it also knows more about which black-letter constraints are actually printed in gray. It can better understand the arguments of its outside lawyers, but it can also better dispute or resist any unwelcome advice. The purported social benefits of the in-house counsel movement center on legal professionals gaining access to the corporate decisionmaking process, but giving lawyers more access does not necessarily guarantee that they will use that access to promote external legal values. ${ }^{29}$ Thus, even the apparently legalizing effects of in-house counsel offices may prove to be illusory: preventive programs may produce compliance with the letter of the law while largely vitiating the law's spirit (Rosen 1989:501, 520); lawyers may participate in business meetings as

29 Nelson et al. note that the converse is true as well: "The autonomy of corporate lawyers does not, by itself, guarantee corporate legality. If lawyers are autonomous but isolated from key information and decisions, they may have little impact on corporate behavior" (1997:4; cf. Stone 1975). 
sources of strategic, rather than cautionary, advice (Nelson et al. 1997:23 ff.); and attorneys who embrace the role of "cop" may find themselves marginalized and displaced by those of their colleagues who adopt a more "entrepreneurial," can-do attitude (ibid., p. 11). Indeed, the very decentralization of in-house legal activity that optimists often extol as a source of grassroots influence can also expose attorneys to intense cooptation pressures (Chayes \& Chayes 1985:289; Nelson et al. 1997) and can undercut the structural capacity of the in-house counsel office to act as a coherent, independent voice in organizational politics (Rosen 1989). The more deeply lawyers are embedded in the organization, the more likely they become to use their expertise to serve, rather than to question, prevailing managerial objectives.

In short, professionalism is not an indivisible whole, and there is no particular reason to think that the internalization of legal expertise will bring with it an equivalent internalization of legal ethics. Despite its newfound access to legal knowledge, the organization as lawyer differs from a traditional lawyer in at least one significant respect: private organizations are generally better able to absorb the bar's technical training than to absorb its normative socialization. Although, as described above, an in-house counsel office may inject certain legal sensibilities into organizational decisionmaking, the reverse influence is often at least as strong. Organizations are themselves powerful engines of socialization, and inside lawyers are as likely to adopt managerial values of profitability, efficiency, and hierarchical authority as to impart legal values of equity, due process, and collegiality. Research suggests, for example, that in their attitudes toward both ADR and litigation ethics, inside attorneys stand midway between their law firm colleagues and their executive superiors (Lande 1995; Suchman 1998). Moreover, the trend among in-house lawyers appears to be toward an increasingly managerial orientation, accompanied by efforts to "market" the legal function to executives as a source of "value added" (Nelson et al. 1997:18-23). In this regard, the organization as lawyer might better be termed the organization as legal expert; through the alchemy of cultural indoctrination and structural constraint, it splits professional skills from professional values, concentrating the former while diluting the latter. Thus, when conflicts arise, the organization as lawyer seems far more likely to use its legal capacity to pursue traditional corporate goals like market dominance and regulatory freedom than to uphold professional norms like civility, fair play, and reasoned deliberation. ${ }^{30}$

30 One might, of course, question whether even the private corporate bar upholds these professional norms in anything but the most hollowly symbolic ways (see Fordham Law Review 1998). Nonetheless, it seems unlikely that in-house practice would be more conducive to legal professionalism than practice in an independent law firm. 
It is here that the in-house counsel hypothesis becomes most troubling for the public governance of organizational activity. Given the already substantial advantages of organizations as repeat players in the legal system, one of the few remaining levers of external social control has traditionally resided in the ability of independent attorneys to identify issues and to frame alternatives, unobtrusively inserting legal standards into nonlegal decisionmaking (cf. Chayes \& Chayes 1985:298). Sociologists have long recognized that the lay/professional interface can be a source of substantial professional discretion and agenda-setting power, and in the traditional configuration of lay organizations and outside attorneys, the position of this interface allowed the Bar to promote and defend its own systemic commitments (such as a commitment to the institutional legitimacy of the formal legal order) in ways that were hard for most managers to second guess. When organizations subsume the lay/professional interface into their own hierarchies, however, the situation changes substantially. Able to assess legal risks and evaluate legal services on its own, the organization as lawyer can filter out professional punctiliousness and can treat outside attorneys as contract laborers, rather than as respected advisors (ibid., p. 298; Rosen 1989:485). Thus, although the in-house counsel movement promises to elevate individual lawyers to pivotal positions in organizational decisionmaking, it represents something of a Faustian bargain for the legal profession as a whole. If in-house counsel come to espouse essentially managerial values (either as a matter of expedience or as a matter of belief), then the internalization of legal expertise may, ironically, reduce the impact of the profession as an agent for the larger legal order. When legal capacity moves to inside the organization, society risks losing whatever leverage an autonomous outside counsel system might otherwise provide. $^{31}$

\section{The Organization as Constable}

Given the relative scarcity of systematic empirical research on private security enforcement, any claims about the character of the organization as constable must remain tentative at best. Nonetheless, the existing evidence suggests that if the private security hypothesis holds true, the internalization of policing may change the law enforcement landscape in several significant

31 One would not, of course, want to overstate this portrayal, because even nominally independent law firms are often beholden to their largest corporate clients and because, in any case, the legal standards nearest outside lawyers' hearts often have more to do with professional prestige than with societal justice (Nelson 1988; Rosen 1989). Nonetheless, research suggests that the ideological and institutional commitments of inside and outside counsel do differ along a number of dimensions and that, of the two groups, outside counsel are generally somewhat more receptive to the messages of the public legal order (see, e.g., Rosen 1989:506; Lande 1995; Nelson et al. 1997). 
ways. In particular, the work of private security forces appears to differ from the work of their public counterparts in at least three regards, which can be designated "visibility/accountability," "intensity/pervasiveness," and "hierarchy/directionality." We examine each of these in turn.

Perhaps the most obvious distinction between private and public policing involves the degree of scrutiny that the two systems typically receive from scholars, the media, elected officials, and the general public. Although public policing is widely studied and intensely debated, private policing goes largely unobserved. ${ }^{32}$ At present, we do not even know the exact number of security officers in the private sector, let alone their demographics, attitudes, or practices (Davis et al. 1991:396). Although a substantial portion of the public criminal caseload originates from private arrests (ibid., p. 407), public agencies rarely gather systematic data on this phenomenon, and no central repository monitors the overall disposition of cases by private security forces. Indeed, the general trend in relations between the private and public systems seems to run in the opposite direction, toward allowing private police to conclude ever more cases without involving public authorities at all. As a result, private security occurs largely outside of the public eye, and its coercive potential rarely attracts the notice of civil libertarian watchdogs.

Along with this difference in visibility, private and public policing also differ in accountability. Not only do private enforcers generally escape the attention of elected officials and public interest groups, but also they largely escape the supervision of the public judiciary. As noted earlier, many of the Constitutional safeguards against abusive policing do not apply to the actions of private parties, especially if those parties are operating on their own property. Thus, aided by protective legislation such as the "merchant privilege" statutes described above, private police can usually go quite far in monitoring, detaining, interrogating, and searching suspected wrongdoers, without even incurring civil tort liability, let alone endangering any subsequent criminal prosecutions. Of course, this lack of public accountability hardly implies that private security forces are entirely masterless. Freed from public supervision, these agencies nevertheless remain tightly linked to their organizational supervisors, and it seems safe to assume that few private police officers could long pursue a line of action that did not serve the organization's larger managerial objectives (Shearing \& Stenning 1983). As Traub (1996:253) puts

32 We do not intend here to disparage the small group of scholars who have labored valiantly in recent years to shed light on private policing activity. Indeed, this article owes much to their efforts. Nonetheless, in quantity if not in quality, a huge disparity remains between these scattered investigations and the surfeit of research, data, and media coverage surrounding public law enforcement. This imbalance, we argue, represents a sociologically interesting phenomenon in its own right. 
it, "[For private police,] crime is defined in instrumental terms, and the interests of the corporate client take precedence over the demands of the law." Although it is certainly true that public police, too, often work in secrecy and often serve powerful special interests, private police clearly stand near the top of the continuum in their insulation from public scrutiny and in their responsiveness to exclusively private purposes.

If in-house security departments were simply a sleepy backwater on the map of social control, the absence of public accountability might prove to be of little consequence. If anything, however, private law enforcement is actually more intensive and pervasive than the public alternative. Indeed, in the current literature, this omnipresence is perhaps the private regime's most widely noted attribute (e.g., Shearing \& Stenning 1981; Marx 1987; Reichman 1987; Davis et al. 1991; Traub 1996). As discussed above, recent estimates suggest that private security officers outnumber public police by a factor of roughly $3: 1$, and the intensity and pervasiveness of private security goes beyond numbers alone. Compared with public law enforcement agencies, police in the private sector are far more proactive, intrusive, and persistent as well.

Mass surveillance provides a telling case in point. For the most part, budgetary and constitutional constraints prevent public law enforcement agencies from engaging in large-scale preventive observation; in contrast, however, the routine monitoring of customers and employees forms a central weapon in the private security arsenal. Moreover, as detailed above, private surveillance goes well beyond traditional "beat patrols" and guardposts, to include both such overtly intrusive techniques as blood and urine testing and also such covertly intrusive techniques as electronic monitoring and computerized background checks. Frequently (albeit perhaps inadvertently), these activities extend the organization's gaze beyond the boundaries of the workplace, into private homes and after-business hours. Although such enforcement efforts again are not unique to the private sector, they occur here with an unusual level of intensity and systematicity. The upshot is that organizational security holds the potential to transform the workplace (and the adjacent precincts of private life) into an expanded version of Bentham's Panopticon, a world in which individuals are deterred and disciplined as much by the internalized fear of observation as by the actual experience of detection and punishment (Bentham 1791; cf. Foucault 1979).

This is not to say, however, that private enforcement systems are in any way lax in detection and punishment. In one study of shoplifting, for example, Davis et al. (1991:400, 407) found that private store police showed much less leniency than even the most aggressive public police forces, releasing only six of $555 \mathrm{de}-$ tainees over a 3-year period while seeking civil recovery (essen- 
tially a stiff fine) from $40 \%$ and passing the remainder along to the criminal justice system for arrest and prosecution. Presumably, a similar pattern holds in other contexts as well, especially in those settings in which the organization can avail itself of internal administrative remedies, such as repossession, firing, or demotion, that do not require any public intervention. Admittedly, the internal equivalent of "prosecutorial discretion" might still prevail if the apprehended individual were a well-connected executive or if the preferred punitive response would trigger a formal grievance proceeding or attract adverse publicity; in the typical case, however, organizational enforcement agents seem far more likely than overburdened public prosecutors to persist to the final punishment. Thus, taken to its logical extreme, organizational policing is not only panoptical but also totalitarian, offering few gaps and interstices to shelter oppositional activity (Marx 1987; cf. Goffmann 1961).

The relentlessness of private policing becomes particularly significant by virtue of its interaction with bureaucratic hierarchy. Because in-house security forces are accountable primarily to management, their legitimacy does not depend on their ability to appear neutral with respect to the organization's stratification system. ${ }^{33}$ Indeed, unlike public police, private police may actually strengthen their political position by being overtly "directional" in their enforcement efforts. Although this does not generally mean that private police can discard objectivity and take partisan positions in organizational turf battles, it does mean that they can systematically adopt different postures toward the top and the bottom of the bureaucratic hierarchy.

This directional bias may appear in many guises, but perhaps the most consequential is the role that private security forces play in focusing the organizational gaze "downward," that is, in exposing the activities of lower-level participants to panoptical surveillance while shrouding the activities of upper-level participants behind a veil of secrecy. Thus, for example, at the same time that they subject employees and customers to routine videotaping, eavesdropping, and background checks, private security personnel also operate the perimeter patrols, telephone scramblers, document shredders, and computer firewalls that protect the ex-

33 Anecdotal evidence suggests that a substantial proportion of private policing is conducted not by large bureaucratic organizations on their own behalf, but rather by smaller security firms, working, in essence, as independent contractors. Although the contrast between these two models may have important consequences for the economic contours of this emerging sector, the distinction seems unlikely to dramatically affect the central questions under consideration here. Presumably, private security officers remain strongly beholden to managerial interests, even when an organization buys their services in "prepackaged" form through a subcontractor. Nonetheless, subtle differences between the two structural arrangements may exist, and future research would do well to consider whether outside security agencies, like outside law firms, display greater responsiveness to nonmanagerial professional norms (and other external legitimacy concerns) than do inhouse departments. 
ecutive suites from prying eyes. In short, private security acts as a sort of one-way mirror, revealing the activities of subordinates to superiors while obscuring the activities of superiors from subordinates. Beyond simply mobilizing public law on behalf of private interests, the internalization of law enforcement therefore plays an active part in the construction of a new organizational regime, one that is uniquely responsive to the control of elites and uniquely fortified against the critiques of the public.

\section{Implications for the Legal Process}

When organizations act as entire private legal systems, rather than simply as repeat players in the traditional public system, they gain increased control over the construction, implementation, and impact of law, not only within their own boundaries, but also throughout their organizational fields. The internalization of each legal role- legislator, adjudicator, lawyer, and constable-adds to the organization's ability to manage, transform, and even supplant external societal rules. It is the merging of these roles, however, that truly cements organizational power, both to regulate social behavior and to constitute social reality (cf. Edelman \& Suchman 1997). Although the consequences of legal internalization are often complex, and although internalization may involve considerable benefits for the "have nots," nonetheless when organizations hold court, the "haves" tend to come out still further ahead.

\section{Internalization as Colonization}

As students of civil litigation have long noted, the stock of potentially adjudicable grievances in society stand in a so-called disputing pyramid, tapering (through a mixture of resolution and attrition) from a broad base of injurious experiences to a narrow crown of formal court decisions (Felstiner et al. 1980). Although public law may remain ensconced at the apex of this pyramid, the internalization of legal roles and processes effectively allows private organizations to colonize the pyramid's lower tiers. $^{34}$ This places such organizations squarely athwart the portals of justice-a strategic position both because it establishes these private bureaucracies as de facto legal gatekeepers and also because, given the geometry of the pyramid, it grants them cus-

34 Technically, of course, the lowest tiers of the disputing pyramid-the "naming" of injuries, the "blaming" of culprits, and the "claiming" of redress (Felstiner et al. 1980)-remain outside even the organizational legal system; internalization, however, serves to insert several additional layers of organizational processing between the emergence of disputes in daily life and the entrance of those disputes into public legal arenas. Thus, as internalization progresses, the first formal institutions that disputants encounter are increasingly likely to be private, not public, in character. 
tody of the only formal disputing arenas that most parties are ever likely to see.

The organizational colonization of disputing begins at the pyramid's base, with organizations' capacity to help shape, in the first place, what constitutes a dispute and what the nature of that dispute is. Superficially, it might seem that organizations play a more limited role in this framing process than does the public legal order: although the public courts use explicit rules about causes of action, mootness, standing, and so on to circumscribe the range of justiciable claims, organizational forums generally purport to hear any complaints that come before them. Selectivity, however, is only one way that a legal system can shape the recognition and definition of disputes, and even without elaborate screening rules, organizations subtly influence the course of dispute construction through the substantive rules they create in their capacity as legislators, the hearings they conduct in their capacity as adjudicators, the advice they dispense in their capacity as lawyers, and the enforcement mechanisms they deploy in their capacity as police. Organizational legal systems may be more reluctant than their public counterparts to proclaim that some grievances are none of their business (Edelman et al. 1993), but this hardly means that the contours of the organizational system will not influence the emergence of disputes. Indeed, by treating all disputes as organizationally adjudicable, the private regime may simply exchange selection and preemption for expanded jurisdiction.

The impact of internalization on the disputing pyramid is not limited, of course, to the anticipatory framing of disputes as they emerge from inchoate injuries into explicit complaints. Once disputes enter the organizational legal system, that system directly influences their elaboration, their progression, their outcomes, and their consequences. Galanter's repeat players enjoyed certain positional advantages in acquiring legal representation, lobbying for rule changes, and persuading courts. Presumably, those advantages continue to accrue to repeat players in the external legal system. In addition, though, today's large bureaucratic organizations-acting as internal legislators, judges, lawyers, and cops-also enjoy the benefits of extensive in-house dispute processing, long before their problem cases might ever come before external authorities. Whereas Galanter's repeat players could hire specialist lawyers to represent them in encounters with the external legal system, today's large bureaucratic organizations are their own lawyers, and they can act in a legal capacity in all phases of their internal and external activities. Whereas Galanter's repeat players could petition public legislatures for favorable legal rules, today's large bureaucratic organizations are their own legislatures, and they can arrange their polities in ways that fundamentally constrain and reconstitute the terms of de- 
bate with their employees and the wider environment, alike. And whereas Galanter's repeat players could develop facilitative relations with court personnel, today's large bureaucratic organizations are their own courts and supply their own court personnel, and they can resolve internal disputes in ways that not only maximize internal organizational peace but also shape the case should it move to the external courts. Perhaps these changes could all be subsumed under Galanter's rubric of using "advance intelligence" to structure transactions, but the emerging pattern goes far beyond the simple negotiation of favorable contractual terms with arm's-length exchange partners. As the sphere of advance planning has widened to include the internalization of law, organizations have moved from holding a position of power within the external legal field to holding, within their own boundaries, a private simulacrum of the field itself (cf. Baudrillard 1994).

To be sure, a number of factors place limits on the organization's ability to colonize the disputing pyramid. Perhaps the most important of these limiting factors is the culture of the organization itself. Internal legal systems, like all legal systems, depend on a supportive cultural context for much of their power, especially their power to frame and transform disputes. Yet, because organizational culture (including organizational legal culture) emerges out of both organizational gestures and participant interpretations, it is never entirely under managerial control. Once created, organizational rules and disputing arenas take on a symbolic status; that is, independent of their official purposes or technical functions, they convey cultural meanings to various audiences. How particular observers interpret such symbolism depends on their social backgrounds, their general views of law and of the organization, their specific past experiences with the symbols in question, and their perceptions of the consistency or inconsistency of symbols and actions (Fuller et al. 2000). Over time, certain interpretations become shared among similarly situated participants, become institutionalized in collective expectations and accounts, and, hence, become part of the organization's legal culture. In predicting the workings of organizational legality, this emergent culture (and the legal consciousness that it implies) may be at least as important as the formal disputeprocessing structures erected by managerial fiat (cf. Ewick \& Silbey 1998).

The precise contours of organizational legal culture-including its degree of coherence or fragmentation and the presence or absence of oppositional subcultures (cf. Martin 1992) - may vary from one site to the next. In all cases, however, cultural meanings will play a significant role in determining whether participants welcome and embrace the organizational colonization of disputing, or whether instead they oppose it as a tool of op- 
pression, or even appropriate it as a vehicle for resistance (Fuller et al. 2000; cf. Merry 1988). Organizational legal culture influences participants' rights consciousness, their attitude toward compliance efforts, their definition of wrongful behavior, and their likelihood of mobilizing the law when perceived violations occur. Organizational culture also influences who employees see as parties to a dispute: In an environment where workplace harassment is common, for example, cultural accounts of rights and responsibilities might influence whether the targets of that harassment blame themselves, their individual harassers, the harassers as a group, the harassers' supervisors, or the organization as a whole (cf. Felstiner et al. 1980). Further, organizational culture interacts with the procedural rules of internal legal forums to affect the nature and timing of dispute resolutions, the perceived justice of those resolutions, and the conditions (if any) under which unsatisfied disputants will take their claims outside the organization to the formal legal realm. In all these ways, organizational culture can play a substantial role in shaping participants' conceptions of what constitutes a dispute and of what (if anything) to do about it. Thus, to a degree, emergent cultural understandings can limit management's ability to control disputing through structural adjustments alone.

As significant as this limitation may be, however, it offers only partial reassurance at best. Although the emergence (or fear) of oppositional cultural accounts may constrain an organization's efforts to internalize legal roles and to supplant public constructions of legality, this countervailing force is itself limited by the interorganizational environment. As suggested above, the internalization of law evolves not only within individual organizations but also within larger organizational fields. If internal rule-making, dispute resolution, legal counseling, and policing were merely idiosyncratic attributes of a single firm, any participants who were inclined toward resistance would find plenty of models and allies beyond that firm's boundaries. However, when the internalization of law is occurring simultaneously in many firms throughout an organizational field-and, indeed, is buttressed by supportive intraorganizational structures at the level of the field itself-even the most disgruntled participants may have trouble enunciating persuasive counterarguments or describing plausible alternatives. Thus, for example, as in-house counsel gain prevalence and prestige, and as bodies such as the American Corporate Counsel Association emerge to carry forward this "professional project" (Abbott 1988), the leadership of the bar becomes ever less likely to voice opposition to the mixing of organizational and legal values (cf. Rosen 1989:490 ff.; Nelson et al. 1997). Similarly, as ADR takes on an increasingly institutionalized status and as bodies such as the Society of Professionals in Dispute Resolution emerge to give it substance and publicity, em- 
ployers, employees, and society in general become ever less likely to question the claim that private organizational proceedings are simply the most rational way of handling disputes in the context of employment or business relations (Edelman, Uggen, \& Erlanger 1999). ${ }^{35}$ As a general matter, organizational culture comes from the interplay of direct experiences in the organization and vicarious exemplars in the organizational environment. Consequently, although opposition to the internalization of law remains a possibility, the simultaneous legalization of organizations and organizational fields tends to promote, not inhibit, the view that legal problems are best addressed by private personnel in private arenas.

\section{Do the "Haves" Still Come Out Ahead?}

Before concluding, it is perhaps worthwhile to revisit, explicitly, the larger question of whether the organizational internalization of law accentuates or moderates the advantages that society's "haves" experience in legal life. On one hand, the previous discussion outlines numerous ways in which recent internalization dynamics have extended organizational authority into ever widening provinces of legal activity, replacing public regulation of organizations with private regulation by organizations. Because the large bureaucracies that are pursuing this annexation generally represent society's "haves," 36 the organizational internalization of law would seem to strengthen the position of social elites and narrow the limits of legal change. On the other hand, however, recent trends include other, more progressive, aspects as well. To the extent that internalization implies the absorption of legal standards, values, and outlooks into organizational decisionmaking, it is possible that the private organizational world is being domesticated by public law and not vice versa.

On the optimistic side, there is good reason to believe that organizations cannot internalize law without, in the process, transforming their own orientations (Selznick 1949). Neoinstitutional sociology, in particular, has demonstrated that legal pro-

35 This shift is evident, for example, in the internalization of civil rights claims. Although public legal authorities may once have seen themselves as the primary guardians of minority rights, by the early 1990 s both legislatures and courts had begun to endorse organizational handling of employment-related discrimination claims. This new attitude can be seen in legislation like the 1991 Civil Rights Act and the 1990 Americans with Disabilities Act, which both endorse ADR, as well as in court decisions like Meritor Savings Bank $v$. Vinson (1986), which suggest that grievance procedures, if proper in form, may protect employers from liability in external legal actions.

36 The identity between large bureaucratic organizations and society's "haves" is, of course, not a perfect one. Some organizations forward the agendas of the poor and downtrodden, and some elites operate through primarily nonorganizational devices. Nonetheless, just as Galanter's one shotter-repeat player typology "define[s] a position of advantage . . . and indicate[s] how those with other advantages tend to occupy this position" (1974:103), so too does formal organization correlate with and augment other advantages in the contemporary stratification regime. 
nouncements (and organizational responses to those pronouncements) can generate a symbolic feedback loop, in which legality comes to be seen as inseparable from efficiency, rationality, and modernity. Not only may law coerce conformity from those organizations that are most vulnerable to direct sanctions (see, e.g., Scott 1987; Fligstein 1991), but also, and more important, the search for acceptable models of compliance may lead organizations to embrace new policies, new outlooks, new structures, and new personnel in ways that permanently alter the basic standards of practice throughout entire organizational fields (Suchman \& Edelman 1996; Edelman \& Suchman 1997). Thus, rather than simply displacing public law, legalization brings public normative commitments and public cognitive frameworks into the decisionmaking dynamics of even those organizations that are not covered by formal legal sanctions (e.g., Edelman 1990). Indeed, even "merely symbolic" compliance can exert lasting substantive effects as it redirects organizational attention, alters the organization's public identity, and draws new sets of participants into the organization's dominant coalition (Edelman \& Petterson 1999).

In light of these findings, one might take internalization as a sign that organizations are, in effect, being "resocialized" by law. In the past, organizations have often adopted a recalcitrant stance toward external regulation-acting arbitrarily, exploitatively, and even dictatorially and then using their advantages as repeat players to prevent aggrieved "have nots" from obtaining meaningful redress through the public courts. In comparison to this bleak alternative, the internalization of law arguably represents a significant (although limited) victory for the forces of reform. As disadvantaged groups have secured increasingly protective rules from the public legal system, managers have attempted to control the resulting legal uncertainty by progressively removing organizational operations from public jurisdiction, but this strategy has proven to be a two-edged sword. To legitimate their jurisdictional claims, organizations have had to legalize their internal polities, often creating at least as many citizenship rights as most underfunded one shotters would have been able to wrest from a passive and overburdened public court system. Organizational rules have become more rational and more clearly linked to valid, publicly articulable goals; organizational dispute resolution procedures have become more accessible, more balanced, and less arbitrary; organizational decisions have become more responsive to the views of legal professionals; and organizational policing efforts have become more objective, more scientific, and less brutal. Taken as a whole, legalization may have profoundly altered the basic character of organizational authority, perhaps to the point where the paradigmatic large bureaucracy is no more an instrument of the "haves" than is the public legal system itself. 
Unfortunately, this account, although not necessarily inaccurate, remains only partial. Internalization may indeed moderate some of the most exploitative features of organizational life, but it does little to make bureaucracy more democratic. To the contrary, when the legal game moves onto an organizational playing field, organizational ground rules tend to prevail. Although liberal legal systems and bureaucratic organizations share a common legal-rational commitment to systematic, objective decisionmaking, they embody largely divergent ideological orientations toward the trade-offs between bottom-up participation and topdown authority, and between individual autonomy and hierarchical control. To date, organizations have been quicker to internalize the public legal system's formalization and systematicity than to embrace its legitimating myths of democratic sovereignty and personal freedom $; 37$ despite extensive legalization, the rationality of organizations remains fundamentally authoritarian and instrumental. Legal pressures may make organizations more rule bound and more paternalistic, but short of redefining corporate personhood, the law is unlikely to make organizations substantially more responsive to voices from below.

This pattern holds true across all four domains of internalization: rule making, dispute processing, legal counseling, and policing. Although the legalization of organizational rules may transform many firms into private polities with extensive "citizenship" rights, these rights seldom include the right to vote, the right to assemble, or even the right to speak. Similarly, although organizational dispute resolution may create new forums for airing employee grievances, these forums tend to embody a managerial logic, allowing little publicity, creating few binding precedents, and favoring largely "therapeutic" restorative remedies, over the vindication of formal rights. In-house attorneys, too, tend to adopt distinctly managerial orientations, entrepreneurially seeking to "add value" to the organization's bottom line (Nelson et al. 1997), but rarely offering pro bono services to aggrieved employees, or engaging in the internal equivalent of "cause lawyering" (cf. Sarat \& Scheingold 1998). Finally, although private security forces increasingly employ the rationalized methods of the public police, they do so with virtually no equivalent constraints on their powers of search, seizure, surveillance and secrecy.

In the end, then, internalization benefits the "haves" not so much because it undercuts legal neutrality or formality, as be-

37 Many observers dispute whether such legitimating myths make much practical difference (see, e.g., Tushnet 1984; cf. Sarat 1998), and our argument here should not be read as a full, substantive defense of the liberal legal model. Nonetheless, at the margins, the democratic and libertarian pretensions of the public legal order at least provide symbolic resources that "have not" groups can invoke to mobilize support in various political debates (Scheingold 1974). Few equivalent symbolic resources exist within the more authoritarian and instrumentalist ideology of bureaucracy. 
cause it undercuts democratic governance. After all, private legal systems are not distinguished by being housed within large organizations; states, too, are large organizations, and states, too, hold legislatures, courts, lawyers, and police. The difference is that, to the extent that states embrace an ethic of participatory democracy (and, admittedly, this is often sadly limited), they tend to build structural safeguards for popular sovereignty and normative commitments to distributional equity. In contrast, most private organizations are constructed to be ruled from the top and are normatively committed to enhancing the welfare of their chiefs. Whereas the archetypal democracy fosters communication and control from the populace to the leadership, the archetypal bureaucracy fosters communication and control from the leadership to the populace. And whereas the archetypal democracy exposes official decisionmaking to publicity and shields individual decisionmaking in privacy, the archetypal bureaucracy shrouds official decisionmaking in secrecy and exposes individual behavior to panoptical surveillance. ${ }^{38}$ If one believes that the welfare of the "have nots" ultimately depends on their effective political mobilization and not on the judiciousness and charity of the "haves" above them, then one should find little to celebrate in the movement of rule making, dispute processing, legal counseling, and policing out of the public legal system and into private organizations. ${ }^{39}$

\section{Future Research}

By their nature, "speculations" open rather than close lines of inquiry. In this article, we have offered hypotheses about the internalization of law; we have gathered a sampling of existing evidence that points, we believe, toward the validity of these hypotheses; and we have explored the possible implications of these

38 We do not intend to argue here that top-down communication, authoritative leadership, official secrecy, and mass surveillance could never have a place in a democratic polity. Nor do we intend to argue that any particular real-world public order fully embodies the democratic ideal (or, for that matter, that any real-world private order fully embodies the bureaucratic alternative). We offer these archetypes simply to highlight the underlying differences between the democratic and bureaucratic logics and to suggest that the distinction between the two may carry substantial implications for the fate of society's "have nots."

39 As an aside, it is perhaps worth noting that the internalization of law by large bureaucracies may represent a sort of "unhappy medium" in the tug of war between public law and indigenous law (see Galanter 1981; Macaulay 1986). When authority resides in the state, the legal order may suffer from excessive artificiality and formalism, but it is also likely to offer substantial protections for democratic access and minority interests. When authority resides in indigenous communities, the legal order may reproduce customary prejudices, exclusions, and favoritisms, but it is also likely to offer grassroots involvement, common-sense familiarity, and a pragmatic foundation in "living law" (Ehrlich [1936] 1962). When, however, authority resides in large bureaucratic organizations, the legal order is likely to be formalized without being democratic, and privatized without being grounded in the grassroots. To that extent, the organizational internalization of law represents the worst of both worlds. 
hypotheses for the fortunes of society's "haves" and "have nots." Our analysis, however, has suggested, not tested; illustrated, not demonstrated; proposed, not concluded. The possible directions for future study are many, and we highlight only a few here.

At the most basic level, more research is needed simply to determine whether, and to what extent, legal internalization has in fact occurred. In particular, because our hypotheses inherently imply change over time, future studies should seek to develop more systematic longitudinal data both on the development of in-house legal systems and on the consequences of those systems for various participant groups. Equally importantly, to move beyond counterfactual hypotheticals ("If law had not been internalized ..."), researchers should search out relevant comparison cases, looking across organizational fields, legal jurisdictions, or nation-states. Internalization probably has not proceeded at an equal pace in all social settings, but to put this variation to good empirical use, we will need far more finegrained observations than the current literature provides.

Assuming that our basic hypotheses withstand such testing, future investigations should extend the inquiry to consider the extent to which the four internalization dynamics work in concert. If in-house counsel draft lawlike policies to govern the workings of internal dispute resolution systems, or if private police bring suspects before internal disciplinary panels for violating organizational rules, resonances among the four trends may dramatically intensify the internalization effect. Conversely, if the four trends all operate at different times, in different settings and upon different subjects, their weave may be too porous to block the gaze of public law.

Finally, and most importantly, scholars should carefully examine how the internalization of law affects the standing of society's "haves" and "have nots." Although our theoretical account suggests that, on balance, the internalization of law expands corporate power vis-à-vis individuals, this thesis deserves thorough testing. Each of our four movements carries with it a justificatory account that promises benefits to "haves" and "have nots" alike; although many aspects of these accounts may be mere puffery, only detailed empirical study can determine whether any important kernels of truth lurk within. In the end, a theory of why the "haves" come out ahead is only as good as the remedies that it suggests. To find appropriate remedies, we must know both the best and the worst that current trends hold in store.

\section{Conclusion}

In the years since Galanter wrote "Why the 'Haves' Come Out Ahead," the legalization of organizational governance, the expansion of private dispute resolution, the rise of in-house coun- 
sel, and the reemergence of private policing appear to have interacted to transform the large bureaucratic organization from being merely a repeat player in the public legal system to being an entire private legal system in its own right. By merging the roles of legislator, administrator, forum, judge, lawyer, and cop, such organizations have colonized the base of the disputing pyramid and have infused it with a distinctly managerial logic. As this colonization has proceeded, the new private legal order has annexed increasingly large segments of territory from the traditional public legal order, subtly shifting the balance between democratic and bureaucratic tendencies in society as a whole. Although "have not" groups may gain some short-run advantages from the introduction of citizenship norms into the workplace, the long-term prognosis seems much less optimistic. The power of repeat players to win disputes and to structure transactions, which Galanter discussed in 1974, simply pales by comparison to the new power that arises when the "haves" hold court.

\section{References}

Abbott, Andrew (1988) The System of Professions: An Essay on the Expert Division of Labor. Chicago: Univ. of Chicago Press.

Ackerman, Deborah L. (1985) "A History of Drug Testing," in R. H. Coombs \& L. J. West, eds., Drug Testing: Issues and Options. New York: Oxford Univ. Press.

American Bar Association (1991) The State of the Legal Profession. Chicago: American Bar Association, Young Lawyers Division.

American Management Association (1997) Electronic Monitoring and Surveillance [online]. Available: 〈http://www.amanet.org/survey/elec97.htm>.

Balbus, Isaac (1977) "Commodity Form and Legal Form: An Essay on the 'Relative Autonomy' of Law," 11 Law $\mathcal{E}$ Society Rev. 571-88.

Bardach, Eugene, \& Robert A. Kagan (1982) Going by the Book: The Problem of Regulatory Unreasonableness. Philadelphia: Temple Univ. Press.

Baron, James N., Frank R. Dobbin, \& P. Devereaux Jennings (1986) "War and Peace: The Evolution of Modern Personnel Administration in U.S. Industry," 92 American J. of Sociology 350-83.

Baudrillard, Jean (1994) Simulacra and Simulation. Ann Arbor: Univ. of Michigan Press.

Becker, Allison (1992) "Survey Shows In-House Pay Up in 1991," The Recorder, 29 Jan., p. 1.

Bentham, Jeremy (1791) Panopticon; or, The Inspection House. London: T. Payne.

Bishop, Thomas B. (1988) "The Law of Shoplifting: A Guide for Lawyers and Merchants," 19 Cumberland Law Rev. 43-74.

Blumberg, Abraham (1967) "The Practice of Law as a Confidence Game: Organizational Cooptation of a Profession," 1 Law E Society Rev. 15-39.

Blumrosen, Alfred W. (1993) Modern Law: The Law Transmission System and Equal Employment Opportunity. Madison: Univ. of Wisconsin Press.

Bohannon, Paul (1965) "The Differing Realms of Law," 67(Suppl.) The American Anthropologist 33-42.

Bureau of Justice Statistics (1999) Law Enforcement Statistics: Summary Findings [online]. Available: <http://www.ojp.usdoj.gov/bjs/lawenf.htm>. 
Bush, Robert A. Baruch (1989) “Mediation and Adjudication, Dispute Resolution and Ideology: An Imaginary Conversation," $3 \mathrm{~J}$. of Contemporary Legal Issues 1-33.

Bush, Robert A. Baruch, \& Joseph P. Folger (1994) The Promise of Mediation: Responding to Conflict through Empowerment and Recognition. San Francisco: Jossey-Bass.

Chaiken, Marcia, \& Jan Chaiken (1987) Public Policing-Privately Provided. Washington, DC: National Institute of Justice.

Chayes, Abram, \& Antonia $\mathrm{H}$. Chayes (1985) "Corporate Counsel and the Elite Law Firm," 37 Stanford Law Rev. 277-300.

CPR Institute for Dispute Resolution (1999) "Focus, Education, and Legitimacy: CPR Celebrates 20 Years of ADR," 17 Altermatives to the High Costs of Litigation 1-2.

Cronin-Harris, Catherine (1997) Building ADR into the Corporate Law Department: ADR Systems Design. New York: CPR Institute for Dispute Resolution.

Cunningham, William C. (1980) Crime and Protection in America: A Study of Private Security and Law Enforcement Resources and Relationships: Executive Summary. Washington, DC: National Institute of Justice, U.S. Department of Justice.

Cunningham, William C., John J. Strauchs, \& Clifford W. Van Meter (1990) Private Security Trends 1970-2000: The Hallorest Report II. Boston: Butterworth-Heinemann.

Curran, B. (1985) The Lawyer Statistical Report: A Statistical Profile of the U.S. Legal Profession in the 1980s. Chicago: American Bar Foundation.

Davis, Melissa G., Richard J. Lundman, \& Ramiro Martinez Jr. (1991) "Private Corporate Justice: Store Police, Shoplifters, and Civil Recovery," 38 Social Problems 395-411.

Dezalay, Yves, \& Bryant Garth (1996) Dealing in Virtue: International Commercial Arbitration and the Construction of a Transnational Legal Order. Chicago: Univ. of Chicago Press.

DiMaggio, Paul J., \& Walter W. Powell (1983) "The Iron Cage Revisited: Institutional Isomorphism and Collective Rationality in Organizational Fields," 48 American Sociological Rev. 147-60.

Dobbin, Frank, John R. Sutton, John W. Meyer, \& W. Richard Scott (1993) "Equal Employment Opportunity Law and the Construction of Internal Labor Markets," 99 American J. of Sociology 396-427.

Economist (1997) "Welcome to the New World of Private Security," 342 (8013) Economist 21-24.

Edelman, Lauren B. (1990) "Legal Environments and Organizational Governance: The Expansion of Due Process in the American Workplace," 95 American J. of Sociology 1401-40.

(1992) "Legal Ambiguity and Symbolic Structures: Organizational Mediation of Civil Rights Law," 97 American J. of Sociology 1531-76.

- (forthcoming) "Constructed Legalities: Socio-Legal Fields and the Endogeneity of Law," in W. Powell \& D. Jones, eds., Bending the Bars of the Iron Cage: Institutional Dynamics and Processes. Chicago: Univ. of Chicago Press.

Edelman, Lauren B., Steven E. Abraham, \& Howard S. Erlanger (1992) "Professional Construction of the Legal Environment: The Inflated Threat of Wrongful Discharge Doctrine" 26 Law E Society Rev. 47-83.

Edelman, Lauren B., \& Mia Cahill (1998) "How Law Matters in Disputing and Dispute Processing (Or, the Contingency of Legal Matter in Alternative Dispute Resolution)," in B. Garth \& A. Sarat, eds., How Law Matters. Evanston, IL: Northwestern Univ. Press.

Edelman Lauren B., Howard S. Erlanger, \& John Lande (1993) "Employers' Handling of Discrimination Complaints: The Transformation of Rights in the Workplace," 27 Law E Society Rev. 497-534. 
Edelman, Lauren B., Sally Riggs Fuller, \& Iona Mara-Drita (forthcoming) "I Live for Golf While You Prefer Tennis: Diversity Rhetoric and the Managerialization of Law," American J. of Sociology.

Edelman, Lauren B., \& Mark C. Suchman (1997) "Legal Environments of Organizations," 23 Annual Rev. of Sociology 479-515.

Edelman, Lauren B., \& Stephen Petterson (1999) "Symbols and Substance in Organizational Response to Civil Rights Law," in K. Leicht, ed., Research in Social Stratification and Mobility, vol. 17. Greenwich, CT: JAI Press.

Edelman, Lauren B., Stephen Petterson, Elizabeth Chambliss, \& Howard S. Erlanger (1991) "Legal Ambiguity and the Politics of Compliance: Affirmative Action Officers' Dilemma," 13 Law E Policy 73-97.

Edelman, Lauren B., Christopher Uggen, \& Howard S. Erlanger (1999) "The Endogeneity of Legal Regulation: Grievance Procedures as Rational Myth," 105 American J. of Sociology 406-54.

Edwards, Richard (1979) Contested Terrain: The Transformation of the Workplace in the Twentieth Century. New York: Basic Books.

Ehrlich, Eugen [1936] (1962) Fundamental Principles of the Sociology of Law. Translated by W. Moll. New York: Russel and Russel.

Ewick, Patricia C., \& Susan S. Silbey (1998) The Common Place of Law: Stories from Everyday Life. Chicago: Univ. of Chicago Press.

Ewing, David W. (1989) Justice on the Job: Resolving Grievances in the Nonunion Workplace. Cambridge: Harvard Business School Press.

Felstiner, William L. F., Richard L. Abel, \& Austin Sarat (1980) "The Emergence and Transformation of Disputes: Naming, Blaming, Claiming . . , , 15 Law Eo Society Rev. 631-54.

Fisher, Roger, \& William Ury (1981) Getting to Yes: Negotiating Agreement without Giving In. Boston: Houghton Mifflin.

Fligstein, Neil (1991) "The Structural Transformation of American Industry: An Institutional Account of the Causes of Diversification in the Largest Firms, 1919-1979," in Powell \& DiMaggio, eds.

Fordham Law Review (1998) "Symposium on Ethics: Beyond the Rules," 67 Fordham Law Rev. 691-883.

Foucault, Michel (1979) Discipline and Punish: The Birth of the Prison. New York: Vintage Books.

Fuller, Sally R., Lauren B. Edelman, \& Sharon Matusik (2000) "Legal Readings: Employees' Interpretation and Enactment of Law," 25 Academy of Management Rev. 200-16.

Galanter, Marc (1974) "Why the 'Haves' Come Out Ahead: Speculations on the Limits of Legal Change,"9 Law E' Society Rev. 95-160.

- (1981) "Justice in Many Rooms: Courts, Private Ordering, and Indigenous Law," $19 \mathrm{~J}$. of Legal Pluralism 1-47. - (1999) Personal communication, Univ. of Wisconsin Law School, Madison, 21 June.

Galanter, Marc, \& Joel Rogers (1991) "A Transformation of American Business Disputing? Some Preliminary Observations." Institute for Legal Studies Working Paper DPRP \#10-3, Madison, WI.

General Accounting Office (1995) "Employment Discrimination: Most PrivateSector Employers Use Alternative Dispute Resolution" (Letter Report, 5 July) GAO/HEHS-95-150. Available: <http://frwebgate.access.gpo.gov>.

Gilson, Ronald J., \& Robert H. Mnookin (1985) "Sharing among the Human Capitalists: An Economic Inquiry into the Corporate Law Firm and How Partners Split Profits," 37 Stanford Law Rev. 313-92.

Goffmann, Erving (1961) Asylums: Essays on the Social Situation of Mental Patients and Other Inmates. New York: Doubleday/Anchor.

Gordon, David M., Richard Edwards, \& Michael Reich (1982) Segmented Work, Divided Workers. Cambridge: Cambridge Univ. Press. 
Gusfield, Joseph (1963) Symbolic Crusade: Status Politics and the American Temperance Movement. Urbana: Univ. of Illinois Press.

Hartwell, Tyler D., Paul D. Steele, Michael T. French, \& Nathaniel F. Rodman (1996) "Prevalence of Drug Testing in the Workplace," 119 (11) Monthly Labor Rev. 35-42.

Hawkins, Keith (1984) Environment and Enforcement: Regulation and the Social Definition of Pollution. Oxford: Clarendon Press.

Heimer, Carol A., \& Lisa R. Staffen (1998) For the Sake of the Children: The Social Organization of Responsibility in the Hospital and the Home. Chicago: Univ. of Chicago Press.

Heinz, John P., \& Edward O. Laumann (1982) Chicago Lawyers: The Social Structure of the Bar. New York: Russell Sage Foundation.

Heinz, John P., Robert L. Nelson, Edward O. Laumann, \& Ethan Michelson (1998) "The Changing Character of Lawyer's Work: Chicago in 1975 and 1995," 32 Law E Society Rev. 751-75.

Jacoby, Sanford M. (1985) Employing Bureaucracy: Managers, Unions, and the Transformation of Work in American Industry, 1900-1945. New York: Columbia Univ. Press.

Joh, Elizabeth (1999) Personal communication, New York University, New York City, 18 June.

Kaye, Judith S. (1996) "Symposium on Business Dispute Resolution: ADR and Beyond: An Opening Statement," 59 Albany Law Rev. 835.

Konrad, Alison M., \& Frank Linnehan (1995) "Formalized HRM Structures: Coordinating Equal Employment Opportunity or Concealing Organizational Practices?" 38 Academy of Management J. 787-820.

Lande, John (1995) "The Diffusion of a Process Pluralist Ideology of Disputing: Factors Affecting Opinions of Business Lawyers and Executives." Ph.D. diss., Department of Sociology, University of Wisconsin-Madison.

(1998) 'Failing Faith in Litigation? A Survey of Business Lawyers' and Executives' Opinions," 3 Harvard Negotiation Law Rev. 1-70.

Lind, E. Allan, \& Tom R. Tyler (1988) The Social Psychology of Procedural Justice. New York: Plenum Press.

Lipsky, David B., \& Ronald L. Seeber (1998) "In Search of Control: The Corporate Embrace of $\mathrm{ADR}$," 1 Univ. of Pennsylvania J. of Labor E' Employment Law 133-57.

Macaulay, Stewart (1963) "Non-Contractual Relations in Business: A Preliminary Study," 28 American Sociological Rev. 55-66.

- (1986) "Private Government," in L. Lipson and S. Wheeler, eds., Law and the Social Sciences. New York: Russell Sage Foundation.

Martin, Joanne (1992) Cultures in Organizations: Three Perspectives. New York: Oxford Univ. Press.

Marx, Gary T. (1987) "The Interweaving of Public and Private Police in Undercover Work," in C. Shearing \& P. Stenning, eds., Private Policing. Beverly Hills, CA: Sage Publications.

May, David (1999) "Testing by Necessity," 68 (4) Occupational Health and Safety $48-51$.

Menkel-Meadow, Carrie (1984) "Toward Another View of Legal Negotiation: The Structure of Problem-Solving," 31 UCLA Law Rev. 754-842.

Merry, Sally E. (1988) "Legal Pluralism," 22 Law E Society Rev. 869-96.

- (1990) Getting Justice and Getting Even: Legal Consciousness among WorkingClass Americans. Chicago: Univ. of Chicago Press.

Mnookin, Robert H., \& Lewis Korhauser (1979) "Bargaining in the Shadow of the Law: The Case of Divorce," 88 Yale Law J. 950-97.

Moore, Christopher W. (1986) The Mediation Process: Practical Strategies for Resolving Conflict. San Francisco: Jossey-Bass.

Morn, Frank (1982) The Eye That Never Sleeps: A History of the Pinkerton National Detective Agency. Bloomington: Univ. of Indiana Press. 
Nelson, Robert L. (1988) Partners with Power: Social Transformation of the Large Law Firm. Berkeley: Univ. of California Press.

(1994) "The Futures of American Lawyers: A Demographic Profile of a Changing Profession in a Changing Society," 44 Case Western Reserve Law Rev. 345-406.

Nelson, Robert L., Laura Beth Nielsen, \& Lisa E. Douglass (1997) "Cops, Counsel, or Entrepreneurs: The Shifting Roles of Lawyers in Large Business Corporations." Presented at the Law \& Society Association Annual Meeting, St. Louis, MO (29 May-1 June).

Nonet, Philippe, \& Philip Selznick (1978) Law and Society in Transition: Toward Responsive Law. New York: Harper and Row.

Perrow, Charles (1991) "A Society of Organizations," 20 Theory E Society 725-62.

Plapinger, Elizabeth (1999) Personal communication, CPR Institute for Dispute Resolution, New York City, 23 June.

Pondy, Louis R., \& Ian I. Mitroff (1979) "Beyond Open System Models of Organization," in B. Staw, ed., Research in Organizational Behavior, vol. 1. Greenwich, CT: JAI Press

Powell, Walter W., \& Paul J. DiMaggio, eds. (1991) The New Institutionalism in Organizational Analysis. Chicago: Univ. of Chicago Press.

Rees, Joseph (1988) Reforming the Workplace: A Study of Self-Regulation in Occupational Safety. Philadelphia: Univ. of Pennsylvania Press.

Reichman, Nancy (1987) "The Widening Webs of Surveillance: Private Police Unraveling Deceptive Claims," in C. Shearing \& P. Stenning, eds., 1987.

Reuben, Richard C. (1996) "The Lawyer Turns Peacemaker," 82 ABA J. 54-62. (1997) "Public Justice: Toward a State Action Theory of Alternative Dispute Resolution," 85 California Law Rev. 577-641.

Rosen, Robert E. (1989) "The Inside Counsel Movement, Professional Judgement, and Organizational Representation," 64 Indiana Law J. 479-553.

Rosenberg, Gerald N. (1991) The Hollow Hope: Can Courts Bring about Social Change? Chicago: Univ. of Chicago Press.

Sarat, Austin (1998) "Going to Court: Access, Autonomy, and the Contradictions of Liberal Legality," in D. Kairys, ed., The Politics of Law: A Progressive Critique, 3d ed. New York: Basic Books.

Sarat, Austin, \& Stuart Scheingold (1998) Cause Lawyering: Political Commitments and Professional Responsibilities. New York: Oxford Univ. Press.

Scheid, Teresa L., \& Mark C. Suchman (1998) "Ritual Conformity to the Americans with Disabilities Act: Coercive and Normative Isomorphism." Unpublished manuscript, Univ. of North Carolina-Charlotte.

Scheingold, Stuart (1974) The Politics of Rights: Lawyers, Public Policy, and Political Change. New Haven, CT: Yale Univ. Press.

Schultz, Vicki (1990) “Telling Stories about Women and Work: Judicial Interpretations of Sex Segregation in the Workplace in Title VII Cases Raising the Lack of Interest Argument," 103 Harvard Law Rev. 1749-1943.

Scott W. Richard (1987) "The Adolescence of Institutional Theory," 32 Administrative Science Q. 493-511.

(1992) Organizations: Rational, Natural, and Open Systems. 3d ed. Englewood Cliffs, NJ: Prentice Hall.

- (1995) Institutions and Organizations. Thousand Oaks, CA: Sage Publications.

Scott, W. Richard, \& John W. Meyer (1983) "The Organization of Societal Sectors," in J. Meyer \& W. Scott, eds., Organizational Environments: Ritual and Rationality. Beverly Hills, CA: Sage Publications.

Selznick, Philip (1948) "Foundations of the Theory of Organization," 13 American Sociological Rev. 25-35.

(1949) TVA and the Grass Roots. Berkeley: Univ. of California Press. 
(1969) Law, Society, and Industrial Justice. New York: Russell Sage Foundation.

Shearing, Clifford D., \& Philip C. Stenning (1981) "Modern Private Security: Its Growth and Implications," in M. Tonry \& N. Morris, eds., Crime and Justice: An Annual Review of Research. Chicago: Univ. of Chicago Press.

(1983) "Private Security: Implications for Social Control," 30 Social Problems 493-506.

—, eds. (1987) Private Policing. Beverly Hills, CA: Sage Publications.

Sitkin, Sim B., \& Robert J. Bies, eds. (1994) The Legalistic Organization. Thousands Oaks, CA: Sage Publications.

Slichter, Sumner (1919) The Tumover of Factory Labor. New York: Appleton.

- (1941) "Union Policies and Industrial Management," Brookings Institution Institute of Economics Publication No. 85, Washington, DC.

Slovak, Jeffrey S. (1979) "Working for Corporate Actors: Social Change and Elite Attorneys in Chicago," American Bar Foundation Research J., pp. 465-500.

Spangler, Eve (1986) Lauyers for Hire: Salaried Professionals at Work. New Haven, CT: Yale Univ. Press.

Spitzer, Steven, \& Andrew T. Scull (1977a) "Privatization and Capitalist Development: The Case of the Private Police," 25 Social Problems 18-29.

- (1977b) "Social Control in Historical Perspective: From Private to Public Responses to Crime," in D. Greenberg, ed., Correction and Punishment. Beverly Hills, CA: Sage Publications.

Stone, Christopher D. (1975) Where the Law Ends: The Social Control of Corporate Behavior. New York: Harper and Row.

Strasser, Fred (1985) "The In-House Lure Gets Stronger," National Law J., 22 July, p. 1.

Suchman, Mark C. (1995a) "Localism and Globalism in Institutional Analysis: The Emergence of Contractual Norms in Venture Finance," in W. R. Scott and S. Christensen, eds., The Institutional Construction of Organizations. Thousand Oaks, CA: Sage Publications.

(1995b) "Managing Legitimacy: Strategic and Institutional Approaches," 20 Academy of Management Rev. 571-610.

- (1997) "On Beyond Interest: Rational, Normative and Cognitive Perspectives in the Social Scientific Study of Law," 3 Wisconsin Law Rev. $475-501$.

(1998) "Working without a Net: The Sociology of Legal Ethics in Corporate Litigation," 67 Fordham Law Rev. 837-74.

Suchman, Mark C., \& Mia L. Cahill (1996) "The Hired-Gun as Facilitator: The Case of Lawyers in Silicon Valley," 21 Law $\mathcal{E}^{2}$ Social Inquiry 679-712.

Suchman, Mark C., \& Lauren B. Edelman (1996) "Legal Rational Myths: The New Institutionalism and the Law and Society Tradition," 21 Law $\mathcal{E}$ Social Inquiry 903-41.

Sutton, John R., Frank Dobbin, John W. Meyer, \& W. Richard Scott (1994) "Legalization of the Workplace," 99 American J. of Sociology 944-71.

Thompson, E. P. (1975) Whigs and Hunters: The Origin of the Black Act. New York: Pantheon Books.

Traub, Stuart H. (1996) "Battling Employee Crime: A Review of Corporate Strategies and Programs," 42 Crime E' Delinquency 244-57.

Tushnet, Mark V. (1984) "An Essay on Rights," 62 Texas Law Rev. 1363-1403.

Weber, Max (1947) The Theory of Social and Economic Organization. New York: Oxford Univ. Press.

Weiss, Robert P. (1987) 'From 'Slugging Detectives' to 'Labor Relations': Policing Labor at Ford, 1930-1947," in C. Shearing \& P. Stenning, eds., 1987.

Westin, Alan F., \& Alfred G. Feliu (1988) Resolving Employment Disputes without Litigation. Washington, DC: Bureau of National Affairs. 


\section{Cases Cited}

Gilmer v. Interstate/Johnson Lane Corp., 111 S. Ct. 1647 (1991).

Mapp v. Ohio, 367 U.S. 643 (1961).

Meritor Savings Bank v. Vinson, 106 S. Ct. 2399 (1986).

Miller v. Bank of America, 600 F.Supp. 161 (1975).

Miranda v. Arizona, 384 U.S. 436 (1966). 
